\title{
Bilişim Teknolojileri Öğretmenlerinin Mesleki Deneyimlerini Dile Getirmede Alternatif Bir İfade Aracı Olarak Dijital
} Hikâye Anlatımı Atölyeleri

\author{
Hatice Çıralı-Sarıca, Yasemin Koçak-Usluel
}

Bilgisayar ve Öğretim Teknolojileri Eğitimi Bölümü, Eğitim Fakültesi, Hacettepe Üniversitesi, Ankara, Türkiye

Sorumlu Yazar: Hatice Çıralı-Sarıca, haticecirali@hacettepe.edu.tr

Makale Türü: Araştırma Makalesi

Bilgilendirme: $\mathrm{Bu}$ makale, birinci yazarın ikinci yazarın danışmanlığında tamamladığı doktora tezine dayalı olarak oluşturulmuştur. Bu makalenin bir bölümü, 12. Uluslararası Bilgisayar ve Öğretim Teknolojileri Sempozyumu'nda sunulmuştur.

Araştırma Desteği: Bu makaleye temel oluşturan araştırmanın bir bölümü, TÜBİTAK 1002- Hızlı Destek Programı tarafından 217K384 kodlu proje desteği ile gerçekleştirilmiştir.

Kaynak Gösterimi: Çıralı-Sarıca, H., Koçak-Usluel, Y. (2020). Bilişim teknolojileri öğretmenlerinin mesleki deneyimlerini dile getirmede alternatif bir ifade aracı olarak dijital hikâye anlatımı atölyeleri. Ë̆itimde Kuram ve Uygulama, 16(2), 120-138. doi: 10.17244/eku.775361

\section{Digital Storytelling Workshops as an Alternative Tool for the Expression of ICT Teachers' Professional Experience}

\author{
Hatice Çıralı Sarıca, Yasemin Koçak Usluel
}

Department of Computer Education and Instructional Technology, Faculty of Education, Hacettepe University, Ankara, Turkey

Corresponding Author: Hatice Çıralı-Sarıca, haticecirali@hacettepe.edu.tr

Article Type: Research Article

Acknowledgement: This article was generated based on the first author's $\mathrm{PhD}$ dissertation prepared under the guidance of the second author. A part of this article was presented in the 12th International Symposium of Computer and Instructional Technology.

Research Funding: A part of the research, which is the basis of this article, was supported by TÜBİTAK (1002 Short Term R\&D Fund Programme - Project No: 217K384).

To Cite This Article: Çıralı-Sarıca, H., Koçak-Usluel, Y. (2020). Bilişim teknolojileri öğretmenlerinin mesleki deneyimlerini dile getirmede alternatif bir ifade aracı olarak dijital hikâye anlatımı atölyeleri. Eğitimde Kuram ve Uygulama, $16(2), 120-138$. doi: $10.17244 /$ eku.775361 


\title{
Bilişim Teknolojileri Öğretmenlerinin Mesleki Deneyimlerini Dile Getirmede Alternatif Bir İfade Aracı Olarak Dijital Hikâye Anlatımı Atölyeleri
}

\author{
Hatice Çıralı-Sarıca, Yasemin Koçak-Usluel \\ Bilgisayar ve Öğretim Teknolojileri Ĕ̆itimi Bölümü, Ĕgitim Fakültesi, Hacettepe Üniversitesi, Ankara, Türkiye \\ ORCID: http://orcid.org/0000-0001-5398-1496 \\ ORCID: http://orcid.org/0000-0002-6147-3333
}

\begin{tabular}{|c|c|}
\hline Öz & Makale Bilgisi \\
\hline $\begin{array}{l}\text { Bu çalışmada, dijital hikâye anlatımı atölyeleri yoluyla Bilişim Teknolojileri (BT) } \\
\text { öğretmenlerinin mesleki yaşamları ile ilgili deneyimlerini ilk ağıdan kendi sesleri ile dile } \\
\text { getirebilmeleri ve bu dile getirilenlerin derinlemesine irdelenerek mesleki anlayışlarının } \\
\text { bütüncül bir biçimde ortaya koyulması amaçlanmı̧şır. Bu amacı gerçekleştirmek için bir } \\
\text { yılda üçü Ankara'da, diğerleri de Elâzığ, Çanakkale ve Denizli’de olmak üzere altı atölye } \\
\text { yapılmıştır. Bu atölyelere katılan } 28 \text { BT öğretmeni çalışmanın katılımcılarını oluşturmuştur. } \\
\text { Aynı zamanda araştırmacı, atölyelerde kolaylaştırıcı olarak yer almıştır. Veriler, } \\
\text { katılımcıların süreçteki tüm anlatılarının ses kayıtları, dijital hikâyeleri, yarı yapılandırılmış } \\
\text { odak grup görüşmeleri ve gözlem notları yoluyla toplanmıştır. Veriler tümevarımsal } \\
\text { kodlama tekniği kullanılarak içerik analizi ile çözümlenmiştir. Analiz sonucunda, } \\
\text { öğretmenlerin mesleki yaşamlarında eğitim politikalarının uygulanışı, öğretim programı, } \\
\text { öğretmen yetiştirme süreci, veli baskısı ve zorbalığı, rol çatışması, derse yönelik algı, sınıf } \\
\text { yönetimi, özel okul uygulamaları, öğretmen yeterlikleri ve altyapı yetersizlikleri ile ilgili } \\
\text { sorunlarla karşılaştıkları ortaya çıkmıştır. Mesleki yaşamlarında karşılaştıkları bu sorunlarla } \\
\text { ilgili olarak bazı öğretmenler uyguladıkları çözümleri, bazıları da çözüm olabileceğini } \\
\text { düşündükleri önerileri atölyelerde paylaşmışlardır. Aynı zamanda atölye sürecinde ortaya } \\
\text { koyulan sorunlarla ilgili birbirleriyle dertleşmişler, kendi süreçlerini gözden geçirmişler, } \\
\text { çıkarım yapmışlar ve yeni çözüm önerileri üretmişlerdir. Sonuç olarak öğretmenler, dijital } \\
\text { hikâye anlatımı atölyeleri yoluyla mesleki deneyimlerini dile getirmişler ve atölyelerin } \\
\text { ürünü olan dijital hikâyelerini oluşturmuşlardır. Böylece bu dijital hikâyelerin dolaşıma } \\
\text { girmesi, bu yolla öğretmenlerin seslerinin daha geniş kitlelere ulaşması ve dile getirilen } \\
\text { konularla ilgili taraflarda farkındalık oluşumuna yönelik somut bir adım atılmıştır. Buradan } \\
\text { hareketle öğretmen adayları için bu dijital hikâyelerin öğretmen eğitiminde kullanılmasının } \\
\text { kuram ve uygulama bağının kurulmasında bir köprü oluşturabileceği ileri sürülebilir. }\end{array}$ & $\begin{array}{l}\text { Anahtar kelimeler: Dijital } \\
\text { hikâye anlatımı, Öğretmen } \\
\text { anlatıları, Bilişim Teknolojileri, } \\
\text { Mesleki yaşam } \\
\text { Makale Geçmişi: } \\
\text { Geliş: } 29 \text { Temmuz } 2020 \\
\text { Düzeltme: } 8 \text { Eylül } 2020 \\
\text { Kabul: } 12 \text { Ekim } 2020\end{array}$ \\
\hline
\end{tabular}

Not: Bu çalışmada, veri toplama sürecine geçilmeden Hacettepe Üniversitesi Etik Komisyonu’ndan 24.04.2017 tarih ve 433 -1543 sayılı etik onay alınmıştır. 


\section{Digital Storytelling Workshops as an Alternative Tool for the Expression of ICT Teachers'}

\section{Professional Experience}

\begin{tabular}{|c|c|}
\hline Abstract & Article Info \\
\hline $\begin{array}{l}\text { This study aims to reveal the professional understanding of ICT teachers in a holistic way } \\
\text { by allowing them to express their experiences regarding their professional lives using their } \\
\text { own voices through digital storytelling workshops and by analyzing their expressions } \\
\text { thoroughly. Accordingly, six digital storytelling workshops were conducted in a year: three } \\
\text { in Ankara and the others in Elazığ, Çanakkale, and Denizli. } 28 \text { ICT teachers participated in } \\
\text { these workshops. Also, the researcher participated as a facilitator in the workshops. The } \\
\text { data were collected through voice recordings of all participants' narratives in the workshops } \\
\text { process, digital stories, semi-structured focus group interviews, and observation notes. The } \\
\text { data were analyzed by content analysis using inductive coding technique. As a result of the } \\
\text { analysis, it was revealed that teachers encountered problems related to the implementation } \\
\text { of educational policies, curriculum, teacher education process, parent pressure and bullying, } \\
\text { role conflict, classroom management, private school practices, teacher competencies, and } \\
\text { infrastructure inadequacies in their professional lives. Some teachers shared the solutions } \\
\text { they applied to these problems, and some of them shared their suggestions. At the same } \\
\text { time, they communicated with each other about the problems, reviewed their professional } \\
\text { lives, made inferences, and produced new solutions during the workshop. As a result, } \\
\text { teachers expressed their professional experiences through digital storytelling workshops } \\
\text { and the digital stories they created in these workshops. In this way, the circulation of these } \\
\text { digital stories represents a concrete step towards enabling teachers to be heard by a wider } \\
\text { audience and raising awareness among the relevant parties on the issues raised. Thus, the } \\
\text { use of these digital stories in teacher education for pre-service teachers can potentially serve } \\
\text { as a bridge between theory and practice. }\end{array}$ & $\begin{array}{l}\text { Keywords: Digital storytelling, } \\
\text { ICT, Professional life, Teacher } \\
\text { narratives } \\
\text { Article History: } \\
\text { Received: } 29 \text { July } 2020 \\
\text { Revised: } 8 \text { September } 2020 \\
\text { Accepted: } 12 \text { October } 2020\end{array}$ \\
\hline
\end{tabular}




\section{Extended Summary}

\section{Introduction}

Digital storytelling (DST) is a workshop-based practice that follows certain stages, based on collaborative work between storytellers and facilitators, and digitalizes personal stories usually about experiences. Digital storytelling workshops (DSTWs) offer many opportunities such as collaborative work, reflection, thinking in-depth, expressing experiences, remembering the past, making people's voices heard, creating new understandings and perspectives, understanding individuals' self and their own lives, and professional development of teachers. In addition, it can be said that studies can be carried out through DSTWs, which can offer a richer data collection opportunity. The data can be obtained sincerely in multiple ways, including narratives, stories, audio recordings, and observation notes during DSTWs, digital stories as the outputs of the workshops, and interviews. This study aims to reveal the professional understanding of ICT teachers in a holistic way by allowing them to express their experiences regarding their professional lives using their own voices through digital storytelling workshops and by analyzing their expressions thoroughly.

\section{Method}

This study is designed within the scope of qualitative research method. This study draws on ethnographic techniques. DST can be used as an ethnographic research technique. The participants were 28 ICT teachers who joined the DSTWs. These 28 teachers work at private and/or public schools in different cities in Turkey and they voluntarily participated in this study. Their information was kept confidential and so they were identified under different names. The data were collected during this study as follows:

- All conversations with the participants were audio-recorded and the researcher as facilitator took participant observation notes during the DSTWs.

- Semi-structured focus group interviews were performed at the end of the in-group screening of DSs.

- The texts of the digital stories were reviewed as the outputs of the DSTWs.

The researcher participated in the DSTWs as facilitator. Six DSTW were conducted in the study, the first three being in Ankara, the fourth in Elazı $\breve{g}$, the fifth in Çanakkale and the last in Denizli. The DSTW process in this study is based on the draft plan of Lambert (2013, p. 75) and the DSTW practice proposed by Şimşek (2012). The following steps were followed for each DSTW: Creating a story circle, writing the story, audio recording, preparing visuals, putting the digital story together and in-group screening. The data were analyzed by content analysis using inductive coding technique. Tables, code-clouds, and code-relationship maps were used for the presentation of the data.

\section{Findings}

Teachers communicated with each other about the professional lives, reviewed their lives, made inferences, and gained new insights during the DSTWs. As a result of the analysis, it was revealed that teachers encountered a range of problems in their professional lives, and while they could deal with some of them, they only came up with suggestions to solve others. The teachers also reported the problems about teacher education process they failed to realize when they were students but came to realize when they started teaching as well as suggested solutions to these problems. These problems and solutions are related to the implementation of educational policies, curriculum, teacher education process, parent pressure and bullying, role conflict, classroom management, private school practices, teacher competencies, and infrastructure inadequacies. Although the problems expressed by teachers were divided into different categories such as the implementation of educational policies, role conflict, classroom management, it was noteworthy that these problems were intertwined with each other, and that a stated problem was the source or result of the other problem. Furthermore, the teachers discussed how the situations they encountered both in their teaching career and in their education process as a pre-service teacher contributed to themselves professionally.

\section{Results and Discussion}

In this study, six different DST workshops with 28 ICT teachers in different cities of Turkey were carried out in oneyear period. Hence, the study adds to the literature by serving as a step for revealing the experiences of the teachers working under different conditions and with different competencies and abilities, specifically the IT teachers, in the educational context of Turkey with their own voices and words through the DST workshops. Additionally, the digital stories as the outputs of the workshops are circulated on http://dijitalhikâyeleregitimde.com/ and http://www.digitalstoryhub.org/. With the circulation of digital stories, it can be said that many opportunities are offered to reach a wider audience of teachers' voices, to raise awareness for the related parties about the issues raised and to use these digital stories in teacher education. Through the use of DSs in teacher education, pre-service teachers can be provided with concrete examples of experiences related to the teaching profession and obtain practical knowledge on school environment, curriculum, communication with parents, etc. In this way, concrete efforts can be made to bridge the gap between theory and practice. Thus, these findings open new perspectives on the use of the digital stories narrated by teachers in DSTWs in teacher education. 


\section{Giriş}

Dijital Hikâye Anlatımı (DHA), hikâye anlatıcıları ile kolaylaştırıcılar arasındaki işbirliği yaklaşımına dayanan, hikâye çemberi adı verilen bir grup sürecinin benimsendiği, belirli aşamaların takip edilerek yürütüldüğü, kişisel hikâyelerin dijitalleştirildiği, atölye temelli bir uygulamadır (Hartley \& McWilliam, 2009, p. 3; Lambert, 2013, pp. 1-75; Şimşek, 2013, s. 281). Dijital hikâye anlatımı atölye (DHAA) sürecinin temel aşamaları; hikâye çemberi, hikâyenin kâğıda dökülmesi, ses kaydı, görsel üretimi, içeriklerin (ses, görsel, vb.) bir araya getirilmesi ve grup için gösterimi olarak siralanabilir (Lambert, 2013; Şimşek, 2013).

Şimşek (2018, ss. 35-43), DHAA süreci aşamalarını diyalojik ve dijital olmak üzere ikiye ayırmaktadır. Yazarın diyalojik aşamalar olarak hikâye çemberi ve grup içi gösterim aşamalarını ele aldığı ve bu aşamaların özünde diyaloğun, kendini ifade etmenin, anlatımın, dinlemenin ve karşılıklı yorum ve işbirliği ile güvenin tesis edildiği bir iletişim sürecinin yer alması nedeniyle böyle bir ayrıma gittiği dikkat çekmektedir. Dijital aşamalar ise sözlü anlatıdan yazıya geçişin söz konusu olduğu, hikâyeye dair notların tutulduğu, ses kayıtlarının yapıldığı ve hikâyelerin dijitalleşmesi için teknolojik araçların kullanıldığı aşamaları kapsamaktadır. DHAA sürecinin aşamaları büyük bir halkanın parçaları olarak ele alınmakta, aşamaların birbirini çizgisel değil de döngüsel bir şekilde takip ettiğine ve grup dinamiğine bağlı olarak bu aşamalar arasında bir geçişkenliğin söz konusu olduğuna vurgu yapılmaktadır (Şimşek, 2013). Ek olarak, DHAA'lara gelen kişilerin sıradan olduğu, sesinin duyulmasını isteyen ve sesi duyulsun istenen kişiler olduğu ve bu süreçte bilgisayar bilgisine gerek olmadığı ifade edilmektedir (Şimşek, 2018). Yazar, süreçte bireylerin bir yandan deneyimleri veya yaşantılarına ilişkin hikâyeler paylaşırken, diğer yandan diğer katılımcıların hikâyelerini, anlatılarını sesleri ve sessizlikleri ile anlamlandıran ve etkin dinleyenleri olduğunu belirtmektedir (Şimşek, 2018).

Alanyazın incelendiğinde DHA konusunda yapılan sistematik tarama çalışmalarından hareketle disiplinler arasında yapılmış birçok çalışma olmasına rağmen atölye temelli yapılan çalışmaların sınırlı olduğu, eğitsel bağlamdaki çalışmaların ise diğer alanlara göre daha sınırlı olduğu söylenebilir (de Jager, Fogarty, Tewson, Lenette, \& Boydell, 2017; Wu \& Chen, 2020). Eğitsel bağlamda DHAA’ların öğrenenler ve öğrenme için duygusal, bilişsel, kavramsal, akademik, teknolojik, dilbilimsel, ontolojik (kimlikle ilişkili) ve sosyal çıktılarının olduğu ifade edilmektedir (Wu \& Chen, 2020). Alanyazında eğitsel bağlamdaki DHAA çalışmalarının sadece öğrenenlerle sınırlı kalmadığı; öğretmenlerin, öğretmen adaylarının, yaşlıların ve hemşirelerin deneyimlerinin mesleki gelişim, öğretmen eğitimi, yetişkin öğrenmesi, yaşam boyu öğrenme ve hemşire eğitimi bağlamında araştırıldığı görülmektedir (Arraiz Matute, Da Silva, Pendleton Jiménez, \& Smith, 2020; Gachago, Ivala, Chigona, \& Condy, 2015; Hausknecht, Vanchu-Orosco, \& Kaufman, 2016; Stacey \& Hardy, 2011; Stenhouse, Tait, Hardy, \& Sumner, 2013; Stewart \& Ivala, 2017; Şimsek \& Erdener, 2012; Van Galen, 2017; Yuksel-Arslan, Yildirim, \& Robin, 2016). Bu çalışmalarda DHAA'ların; işbirlikli çalışmaya, derinlemesine düşünmeye, deneyimlerin ifade edilmesine, geçmişin hatırlanarak gözden geçirilmesine, kişilerin seslerini duyurmasına, yeni anlayışların ve bakış açılarının oluşumuna, kendini ve kendi yaşamlarını anlamaya, ortak bir aidiyet duygusu gelişimine, firsat eşitliğine, öz-güven gelişimine, mesleki gelişime katkı sağladığ 1 ve bir öğretme-öğrenme arac1 olma potansiyeli taşıdığı söylenebilir. Eğitsel bağlamda DHA konusunda Türkiye'de var olan durum incelendiğinde, yaşantıları ve deneyimleri anlamaya yönelik bir DHAA sürecinden ziyade DHA'nın dijital kısmına odaklanılarak bireysel beceri geliştirme hedefinin ağırlıklı olduğu çalışmaların yürütüldüğü belirtilmektedir (Şimşek, Usluel, Sarıca, \& Tekeli, 2018). Şimşek (2018) ise Türkiye'de iletişim çalışmaları bağlamında yürüttüğü DHA çalışmaları ile toplumda sesi fazlaca duyulmayanların kendi deneyimlerinin ve sözlerinin kendi sesleri ile aktarmaya olanak sağlandığına dikkat çekmektedir. Yazar, çalıştığı gruplar bağlamında DHA'yı katılımcıların kendilerini temsili için kullanabilecekleri alternatif bir ifade aracı olarak görmekte ve deneyimden gelen bilginin dolaşımına ihtiyaç olduğunu belirtmektedir (Şimşek, 2018). Buradan hareketle bu çalışmada, bilişim teknolojileri (BT) öğretmenlerinin, işbirlikli bir yaratım süreci içerisinde mesleki yaşamları ile ilgili geçmiş deneyimlerinin derinlemesine düşünülmesi, hatırlanması, gözden geçirilmesi, bu deneyimlerin ilk ağızdan kendi sesleri ile dile getirilmesi ve seslerinin duyurulmasının bir aracı olarak DHAA'ların yürütülmesi ve bu süreç sonunda ortaya çıkan dijital hikâyelerin (DH) dolaşıma sokulması amaçlanmıştır. Dolaşıma sokulan DH'lerle öğretmenlerin deneyimlerinden gelen bilgilerinin aktarılması, öğretmen eğitiminde otantik uygulama örneklerine erişimin sağlanmasını beraberinde getirebilir. Böylece, DH'ler kuram ve uygulama bağının kurulabilmesinde köprü işlevi oluşturarak hem uygulama hem de kuramsal tartışmalar için çıkış noktası olabilir.

Diğer bir yandan, Türkiye'de BT öğretmenlerinin mesleklerine yönelik görüş, tutum, kaygı, duygularının; üstlendikleri rollerin, onlardan beklentilerinin, mesleklerinde karşılaştıkları sorun ve çözüm önerilerinin incelendiği çalışmaların yapıldığı görülmektedir (Atal Köysüren \& Deryakulu, 2017; Bahçeci \& Genç, 2013; Deryakulu \& AkbabaAltun, 2014; Deryakulu, 2006; Erçetin \& Durak, 2017; Erdoğan vd., 2010; Eren \& Uluuysal, 2012; Şişman-Eren \& Şahin-İzmirli, 2012; Topu \& Göktaş, 2012; Yeşiltepe \& Erdoğan, 2013). Bu çalışmalarda verilerin, daha çok yarı yapılandırılmış görüşmeler ve anketler, bunlara ek olarak video kayıtları ve günlükler yoluyla toplandığı görülmektedir. Bu noktada, daha zengin bir veri toplama olanağı sunabilecek olan DHAA'lar yoluyla çalışmaların yürütülebileceği söylenebilir. Nitekim DHAA'lar anlatım üzerine kuruludur. Süreçte katılımc1lar bir güven ortamı oluşturarak içten ve rahat bir şekilde birbirlerine açılabilmektedir. Alanyazında DHAA'ların katılımcıların kendilerini rahatça açabildiği güven ortamını sağladığı, kolaylaştırıcı ve katılımcılar arasında kendini ifade etmenin, anlatımın, dinlemenin ve 
karşıllklı yorum ve işbirliği ile güvenin tesis edildiği bir iletişim sürecinin olduğu belirtilmektedir (Stacey \& Hardy, 2011; Stenhouse et al. , 2013; Şimşek, 2018; Oğuz, 2015). Araştırmacı kendisi de süreçte kolaylaştırıcı ya da katılımc1 olarak yer alabilmektedir. Araştırmacı süreci yön vererek cevap aradığı sorulara süreçte içtenlikle cevap bulabilme fırsatı yakalayabilmektedir. Böylelikle işbirlikli bir süreci kapsayan grup pratiği içinde veriler, süreçteki katılımcıların anlatıları, hikâyeleri, ses kayıtları, süreç sonunda ürettikleri DH ve bunlara ek yapılan görüşmeler olmak üzere çoklu yollarla içten bir şekilde elde edilebilmektedir. BT alanında yapılmış çalışmalar, öğretmenlerin sorunları, çözüm önerileri, sınıf yönetimi, vb. belirli kategoriler altında sınırlı bir bağlamda ele alınırken, bu çalışmada DHAA'larda BT öğretmenlerinin mesleki yaşamlarına ilişkin anlatılarında herhangi bir sınırlamaya gidilmeyerek ve verilerin çoklu yollarla toplanması sağlanarak sürecin bütünsel bir bakış açıdan ortaya koyulması amaçlanmaktadır.

\section{Araştırmanın Amacı ve Önemi}

Bu çalışmada, DHAA'lar yoluyla BT öğretmenlerinin mesleki yaşamları ile ilgili deneyimlerini ilk ağızdan kendi sesleri ile süreç boyunca çoklu yollarla dile getirebilmeleri ve bu dile getirilenlerin derinlemesine irdelenerek mesleki anlayışlarının bütüncül bir biçimde ortaya koyulması amaçlanmıştır. Bu amaç doğrultusunda DHAA'lar BT öğretmenlerini ortak alanlara çekebilme, mesleki deneyimlerini paylaşabilme, mesleki yaşamlarında karşılaştıkları önemli durumları belirleyebilme, sorunlarla ilgili dertleşebilme ve bu sorunlara ortaklaşa çözüm üretebilme konularında fırsat sunmaktadır. Böylece öğretmenlerin mesleki gelişimlerine katkı sağlanabileceği söylenebilir. DHAA'ların ürünü olarak her bir öğretmenin üretmiş olduğu DH'leri yoluyla kendilerini yansitabilme, bu DH'lerin dolaşıma girmesi ile branşları ile ilgili farkındalık oluşturabilme ve çözüme ulaşmasını istedikleri konularda kendi seslerini duyurabilmelerine yönelik firsatların sunulacağı söylenebilir. Ek olarak, bu DH'lerle öğretmenlerin deneyimden gelen bilgilerinin aktarılabileceği, DH’lerin öğretmen eğitiminde kullanabileceği böylelikle kuram ve uygulama bağının kurulmasında rol oynayabileceği düşünülmektedir.

\section{Yöntem}

$\mathrm{Bu}$ çalışma, nitel araştırma yaklaşımlarından biri olan etnografik yöntem ile gerçekleştirilmiştir. Etnografinin "kültürü yazarak ortaya koymak, kısaca hikâye anlatmak" olduğu ifade edilmektedir (Ang, 1989, p. 27). Şimşek (2013, s. 303) ise etnografiyi "akademik bir disiplin içinde yaşanmışlıklara dair hikâyeleri kategorize etme ve anlamlandırma çabası" olarak tanımlamaktadır. Ek olarak, DHAA'nın etnografik bir araştırma tekniği olarak kullanılabileceği belirtilmektedir (Oğuz, 2015). Nuñez-Janes (2016) ise DH'lerin eğitsel etnografik çalışmalar için katkılarına dikkat çekmektedir: DH'ler aracılığıyla samimi alanlara davet edildiğimiz; görsellerin, sesin ve anıların açığa çıkarılıp birleşimi ile insanlığın ortak alanlarına çekildiğimiz belirtilmektedir. Ayrıca insanlık meselelerimizle ilgili önemli bir antropolojik dersi hatırlattığ ifade edilmektedir. Bu samimi hikâyelerin etnografik araştırmacılar için önemli olduğu çünkü her bir benzersiz deneyim yoluyla insanlığımızla ilgili ortak noktalar hakkında konuşulduğu dile getirilmektedir. DH'ler ile kişilerin kendi seslerini duyduğumuzu, eşsiz yüzlerini gördüğümüzü ve belirli deneyimlerimizin önemini silip homojenize etmeden insanlığımızdaki benzerlikler hakkında nasıl konuşabileceğimiz ile ilgili düşünmemiz gerektiğine dikkat çekilmektedir. Bu çalışmada, veri toplama sürecine geçilmeden Hacettepe Üniversitesi Etik Komisyonu'ndan 24.04.2017 tarih ve 4331543 sayılı etik onay alınmıştır.

\section{Katılımcilar}

Katılımcılar, altı farklı DHAA'ya katılan toplam 28 BT öğretmeninden oluşmaktadır. Birinci atölye (Ankara) çalışmasına üç; ikinci (Ankara), üçüncü (Ankara) ve dördüncü atölyeye (Elazı̆̆) beş; beşinci (Çanakkale) atölyeye dört ve son olarak da altıncı atölyeye (Denizli) altı kişi katılmıştır. Çalışmaya katılan öğretmenler, özel ve/veya devlet okullarında farklı illerde, farklı kademelerde görev yapan, farklı deneyim yılına sahip çalışmaya gönüllü olarak katılmak isteyenler arasından seçilmiştir. Çalışmada katılımcıların bilgilerinin gizli tutulmasına yönelik katılımcı isimleri farklı olarak kodlanmıştır.

\section{Verilerin Toplanması}

Veri toplama sürecinde;

- Katılımcıların DHAA sürecindeki tüm anlatıları, hikâyeleri ve konuşmaları ses kaydına alınmıştır.

- Araştırmacı, kolaylaştırıcı olarak yer aldığı DHAA'larda bir yandan sürecin işleyişine diğer yandan katılımcıların davranışlarına ilişkin gözlem notları tutmuştur.

- DHAA'ların çıktısı olan DH'ler alınmıştır.

- Süreç sonunda katılımcılarla yarı yapılandırılmış odak grup görüşmeleri yapılmıştır.

\section{Uygulama Süreci}

Çalışma kapsamında ilk üçü Ankara (atölyelerin yapıldığı tarih aralığı sırasıyla 16 Aralık 2017 - 6 Ocak 2018, 22 - 25 Ocak 2018, 10- 17 Şubat 2018), dördüncüsü Elâzığ (20- 21 Ekim 2018), beşincisi Çanakkale (25 Kasım - 2 Aralık 
2018) ve sonuncusu da Denizli'de (22 Aralık 2018 - 5 Ocak 2019) olmak üzere altı DHAA yürütülmüştür. DHAA'ların yürütülme zamanları ve çalışma ortamı katılımcıların isteği doğrultusunda ayarlanmıştır. Ankara' daki katılımcıların tümü yer olarak araştırmacının çalıştığı kurumda bir araya gelmeyi tercih etmişlerdir. Bu atölyelerin tümü araştırmacının çalıştığı kurumdaki laboratuvar ortamında gerçekleştirilmiştir. Katılımcıların bazıları çalışmalarını kendi kişisel dizüstü bilgisayarlarını, bazıları da laboratuvar ortamındaki bilgisayarları kullanarak yürütmüşlerdir. Elazığ, Çanakkale ve Denizli'deki atölyelerin gerçekleştirileceği yer konusunda ise katılımcılar ile iletişime geçilip onların önerisi ile birlikte karar verilerek yer ayarlanmıştır. Katılımcılar süreçte çalışmalarını kendi kişisel dizüstü bilgisayarlarını kullanarak yürütmüşlerdir.

DHAA'ların güvene dayalı bir ortam sağlanarak yürütülmesine yönelik olarak uygulama sürecinde araştırmacı ve katılımcılar dışında ortama başka kişilerin katılmasına izin verilmemiştir. DHAA sürecinin başında herkesin eşit konuşma hakkına sahip olduğu, konuşulanlara ve konuşana saygı duyulması gerektiği, konuşulanların orada kalacağı, istedikleri zaman katılımcıların çalışmadan ayrılabilecekleri ile ilgili açıklamalar yapılmıştır. Öğretmenlerin DH'lerinin dolaşıma girme süreci ile ilgili olarak da onlara, isterlerse anonim isimlerle DH'lerini oluşturup yayınlanabileceği bilgisi verilmiştir. Katılımcılardan sürece gönüllü katıldıkları ile ilgili olarak ve DH’lerinin dolaşıma girmesine izin verdiklerine dair yazılı onay formu alınmıştır.

Her bir DHAA sürecinde araştırmacı kolaylaştırıcı olarak yer almıştır. Kolaylaştırıcı/lar, kendilerinin de en az bir kez bir DHAA'ya katılarak, kendi yaşamlarından bir hikâyeyi dijitalleştiren ve atölye sürecinde katılımcıların işlerini kolaylaştıran kişiler olarak tanımlanmaktadır (Lambert, 2013; Şimşek, 2018).

Bu çalışmada DHAA'ların yürütülme süreci ile ilgili olarak Lambert (2013, p. 75)'ın taslak planı göz önünde bulundurulmuş ve Şimşek (2013)'in atölye süreci temele alınmıştır. DHAA süreci ile ilgili olarak bazı gruplarda benzerlik olsa da grup dinamiğine göre bu sürecin farklılık gösterdiği ortaya çıkmıştır. Nitekim DHAA sürecinin aşamalarının büyük bir halkanın parçaları olduğu, aşamaların birbirini çizgisel değil de döngüsel bir şekilde takip ettiği ve grup dinamiğine bağlı olarak bu aşamalar arasında bir geçişkenliğin söz konusu olduğuna vurgu yapılmaktadır (Şimşek, 2013). DHAA sürecinin her bir aşamasında yapılanlar şöyle sıralanabilir:

Hikâye çemberinin oluşturulması: Bu aşamada çember şeklinde bir oturum düzeni sağlanarak ilk olarak katılımcıların birbirlerine 1sınmaları ve tanımalarına yönelik küçük etkinlikler yapılmıştır. Araştırmacı kolaylaştırıcı olarak süreci başlatan kişi olmuştur. Anlatım sürecinde herhangi bir konuşma sırası takip edilmemiştir. Sonrasında mesleki yaşantılarda karşılaşılan olaylara, durumlara, deneyimlere ilişkin anlatılara yer verilmiştir. Bu anlatımlardan sonra DH'de yer verilmek istenen hikâyeler üzerine odaklanılarak konuşulmuştur.

Hikâyenin kâğıda dökülmesi: Hikâye çemberindeki anlatılardan hareketle katılımcılar, DH'sinde yer vermek istedikleri hikâyelerini kâğıda aktarmışlardır. Şimşek (2013)'ten hareketle katılımcılara, bu aşamanın kişiler için gerginlik oluşturabildiği ve bu aşamanın sadece ses kaydını kolaylaştırmak için yapılan bir aşama olduğu ve olabildiğince az editöral müdahalenin olması gerektiği vurgusu yapılmıştır. Ayrıca, Lambert (2013)'tan hareketle bir hikâye metninin 250-375 kelime aralığında ideal olduğu ifade edilmiştir.

Ses kaydının yapılması: Bu aşamada her bir katılımeı kendi hikâyesini seslendirmiştir. Ses kayıtları, açık kaynak bir yazılım olan "Audacity” aracılığılyla yapılmıştır.

Görsellerin hazırlanması: Bu aşamada görseller kişinin kendine ait ya da internetten telif haklarına dikkat ederek indirebileceği fotoğrafları olabileceği gibi; el ile ya da çeşitli uygulamalar, yazılımlar aracılığı çizebileceği görseller ya da video parçacıkları da olabilir. Ne tür görseller kullanılacaklarının seçimi, kişinin kendisine bırakılmıştır. Bu aşamada katılımcılara, kendilerinin sahibi olmadıkları görselleri kullanmaları durumuna yönelik "Creative Commons" lisansları konusunda bilgilendirme yapılmıştır.

Dijital hikâyenin bir araya getirilmesi: Bu aşamada ses kayıtları, görseller, müzikler, vb. içerikler birleştirilerek video formatına dönüş̧ürülmüş̧ür. Bu aşamada kullanılabilecek birçok web tabanlı ortam, masaüstü yazılım ve mobil uygulama bulunmaktadır. Bununla ilgili katılımcılara yararlanabilecekleri araçlara ilişkin liste verilmiş ve kullanmak istedikleri araçların seçimi kendilerine bırakılmıştır. Ayrıca, bir DH'nin uzunluğunun iki ile dört dakika aralığında ideal olduğu ifade edilmiştir (Lambert, 2013).

Grup içi gösterim: $\mathrm{Bu}$ aşamada $\mathrm{DH}$ 'ler grup içinde izlenmiş, dönütler alınmış, katılımcıların gerekli gördügü noktalarda DH sahibinin isteği doğrultusunda DH'ler üzerinde tekrardan düzenlemeler yapılmıştır.

Öğretmenlerin anlatmış oldukları DH'ler http://dijitalhikâyeleregitimde.com/ ve http://www.digitalstoryhub.org/ adresleri üzerinden dolaşıma sokulmuştur. Bu konuda öğretmenlerden DH'lerinin yayınlanması ve dolaşıma sokulması konusunda gerekli yazılı izinler alınmıştır.

\section{Verilerin Analiz Edilmesi}

Veriler, içerik analizi yoluyla çözümlenmiştir. İçerik analizi, kullanılan bağlamla ilgili olarak metinlerden ya da diğer anlamlı içeriklerden bilimsel yöntemlere dayalı (güvenilir, geçerli, vb.) olarak çıkarımlar yapmak için kullanılan bir yöntem olarak açıklanmaktadır (Krippendorff, 2004; Neuendorf, 2002). 
Verilerin kodlamasında Miles ve Huberman (2015)'ın belirtmiş olduğu tümevarımsal kodlama tekniği kullanılmıştır. Verilerin analizinde MAXQDA 2018 programı kullanılmıştır. Analiz edilen verilerin kod, kategori ve temalar halinde sunumu için tabloların yanı sıra kod bulutlarından ve kod-ilişki haritalarından yararlanılmıştır. Kod bulutlarında, kodlama yoğunluğu fazla olan kodlar kalın ve büyük harflerle vurgulanmaktadır. Kod-ilişki haritalarındaki okların kalınlıkları ise ilişkilerin yoğunluğunu göstermektedir.

\section{Çalışmanın Geçerliği ve Güvenirliği}

Nitel çalışmalarda geçerlik ve güvenirlik kavramları yerine inandırıcılık, aktarılabilirlik ve tutarlılığın ön plana çıktığı söylenebilir. Buradan hareketle bu çalışmanın inandırıcılığına ilişkin, veriler analiz edildikten sonra ortaya çıkan kodlamalar üç alan uzmanı tarafından incelenerek güncellemeler yapılmıştır. Ek olarak, katılımcı çeşitliliğine dikkat edilmiş, verilerin toplanmasında da çeşitlemeye gidilmiştir. Araştırmacı, DHAA'ların yürütülmesi sürecinde kolaylaştırıcı olarak tüm aşamalarda yer almış, süreç sonrasında da katılımcılarla iletişim halinde kalarak uzun süreli etkileşim sağlamıștır. Verilerin analizi sürecinde soru işareti olan, anlaşılmayan, eksik kalan yerlerde katılımcılarla tekrar iletişime geçilerek ek görüşmeler yapılmıştır. Çalışmanın aktarılabilirliğine ilişkin, bulgular yorumlanırken ayrıntılı betimlemelere, alıntılara yer verilmiştir. Çalışmanın tutarlılı̆̆ına ilişkin, sınıf içi korelasyon katsayısı (Intraclass Correlation Coefficient (ICC)) hesaplanmıştır. Bu süreçte bir yandan transkriptlerinden kodlanan metin bölümünün \%10’u rastgele seçilmiş, diğer yandan da kod listesi oluşturulmuştur. Bu oluşturulan iki belge kodlayıcılara gönderilerek kod metinleri ile kodların eşleştirilmesi istenmiştir. Üç kodlayıcı tarafından bağımsız olarak yapılan kodlamalara ilişkin verilerin SPSS programı kullanılarak sınıf içi korelasyon katsayısı hesaplanarak 0.879 bulunmuştur. Buradan hareketle sonuçların güvenilir olduğu söylenebilir.

\section{Bulgular}

BT öğretmenleri DHAA süreçlerinde hikâye çemberinde başlayarak, DH'lerini oluşturma süreci boyunca ve oluşturmuş oldukları DH'lerinde mesleki yaşamları ile ilgili deneyimlerini ilk ağızdan kendi sesleri ile içten, samimi ve güvene dayalı bir ortamda dile getirmişlerdir. Öğretmenler bu süreçte kimi zaman kendileri için önemli, unutamadıkları ve dönüm noktası olan anılarını anlatmışlar ve birbirlerine içlerini dökmüşler kimi zaman da birbirlerinin anlatılarından hareketle bir yandan geçmişe yolculuğa çıkarak mesleki yaşamlarını tekrar gözden geçirirken diğer yandan da geleceğe ilişkin neler yapabilecekleri konusunda çıkarımlarda bulunmuşlardır.

Öğretmenlerin DHAA sürecindeki tüm anlatıları, süreç sonunda öğretmenlerle yapılan odak grup görüşmeleri, bu atölyelerin çıktısı olan her bir öğretmenin DH'leri ve kolaylaştırıcı tarafından tutulan gözlem notları ile ilgili verilerin birlikte analiz edilmesi sonucunda öğretmenlerin mesleki yaşamlarında çeşitli sorunlarla karşılaştıkları ve bu sorunların bazılarına çözüm bulurken bazılarına ise sadece çözüm önerisi getirebildikleri belirlenmiştir. Diğer yandan öğretmenler hem öğretmenlik mesleği yaparken hem de öğretmen adayı olarak yetişme süreçlerinde karşılaştıkları durumların mesleki yaşamda kendilerine olan katkılarını dile getirmişlerdir. Ayrıca öğretmenler, öğretmen yetiştirme sürecine ilişkin kendileri öğrenciyken fark edemedikleri fakat öğretmenliğe başladıktan sonra fark ettikleri sorunları ve bu sorunlarla ilgili çözüm önerilerini ortaya koymuşlardır. Bu temalar ve kodlama yoğunlukları (KY) Tablo 1'de verilmiştir. KY, ilgili konunun öğretmenler tarafından dile getirilme yoğunluğunu göstermektedir.

Tablo 1. Öğretmenlerin dile getirdikleri durumlara ilişkin temalar ve kodlama yoğunlukları

\begin{tabular}{llc}
\hline & & \multicolumn{1}{c}{ Temalar } \\
\hline 1. & Öğretmenlerin mesleki yaşamda karşılaştıkları sorunlar & 625 \\
2. & Öğretmenlerin mesleki yaşamda karşıştıkları sorunlara önerdikleri çözümler & 19 \\
3. & Ögretmenlerin mesleki yaşamda karşılaştıkları sorunlara uyguladıkları çözümler & 218 \\
4. & Mesleki yaşamın öğretmenlere katkıları & 127 \\
5. & Öğretmen yetiştirme sürecinin öğretmenlere katkıları & 8 \\
6. & Öğretmenlerin öğretmen yetiştirme süreci ile ilgili fark ettikleri sorunlar & 112 \\
7. & Öğretmenlerin öğretmen yetiştirme sürecindeki sorunlara önerdikleri çözümler & 38 \\
\hline
\end{tabular}

Tablo 1'de yer alan öğretmenlerin dile getirdikleri bu durumların eğitim politikalarının uygulanışı, öğretim programı, vb. konularda olduğu ortaya çıkmıştır. Buradan hareketle Tablo 1'de yer alan temalar ve bu temalarda yer alan kategorilere Tablo 2'de yer verilmiştir. Tablo 2'nin üst satırında tema numaraları, sol sütunda kategori başlıkları, satır ve sütunların kesişimi hücrelerinde eğer kodlama varsa KY verilmiştir. Böylece, kesişen hücrelere bakıldığında hangi temada hangi kategorinin olup olmadığı KY ile birlikte görülebilmektedir. Örneğin, Tablo 2'de görüldüğü üzere, üçüncü tema olan öğretmenlerin mesleki yaşamda karşlaş̧ıkları sorunlara uyguladıkları çözümlerin öğretmen yeterlikleri, rol çatışması, alt yap ve sınıf yönetimi kategorilerindeki konularla ilgili olduğu ortaya çıkmıştır. 
Tablo 2. Öğretmenlerin dile getirdikleri durumlara ilişkin temalar, kategoriler ve KY

\begin{tabular}{|c|c|c|c|c|c|c|c|}
\hline \multirow{2}{*}{ Kategoriler } & \multicolumn{7}{|c|}{ Tema No } \\
\hline & 1 & 2 & 3 & 4 & 5 & 6 & 7 \\
\hline Öğretmen yeterlikleri & 92 & 4 & 168 & 111 & 8 & - & - \\
\hline Öğretim elemanı yeterlikleri & - & - & - & - & - & 29 & - \\
\hline Öğretim programı & 22 & - & - & - & - & 83 & 30 \\
\hline Rol çatışması & 207 & - & 6 & - & - & - & - \\
\hline Eğitim politikalarının uygulanışı & 82 & 9 & - & - & - & - & - \\
\hline Bireysel ve toplumsal değer algisı & 166 & - & - & - & - & - & - \\
\hline Altyap1 & 77 & - & 32 & 6 & - & - & - \\
\hline Sinıf yönetimi & 41 & - & 10 & - & - & - & - \\
\hline Özel okul uygulamaları & 16 & - & - & - & - & - & - \\
\hline Mesleki statü & 9 & 5 & - & 5 & - & - & - \\
\hline Veli baskısı ve zorbalığ 1 & 6 & - & - & - & - & - & - \\
\hline Toplumsal koşullar & 7 & - & - & - & - & - & - \\
\hline Yönetsel destek & - & - & - & 5 & - & - & - \\
\hline Öğretmen yetiştirme süreci & - & - & - & - & - & - & 5 \\
\hline Öğretmen adayı yeterlikleri & - & - & - & - & - & - & 3 \\
\hline
\end{tabular}

Bulgular, temalar ve temalar altında yer alan kategoriler temel alınarak aşağıda sırasıyla açıklanmıştır.

\section{Öğretmenlerin Mesleki Yaşamda Karşılaştıkları Sorunlar}

Öğretmenlerin DHAA sürecinde ve süreç sonunda ortaya çıkan DH'lerinde daha çok yaşadıkları sorunları dile getirdikleri dikkati çekmiştir. Öğretmenlerin sorunlarla ilgili olarak kategori bazında hangi sorunların yoğun olarak dile getirildiği kod bulutları ile görselleştirilmiştir (Şekil 1). Şekil 1 incelendiğinde örneğin, rol çatışması kategorisinde kodların yazılışının kalınlığına bakılarak "teknik her işin yapılması istenerek teknik eleman gibi çalışmak" sorununun en yoğun olarak dile getirildiği söylenebilir.

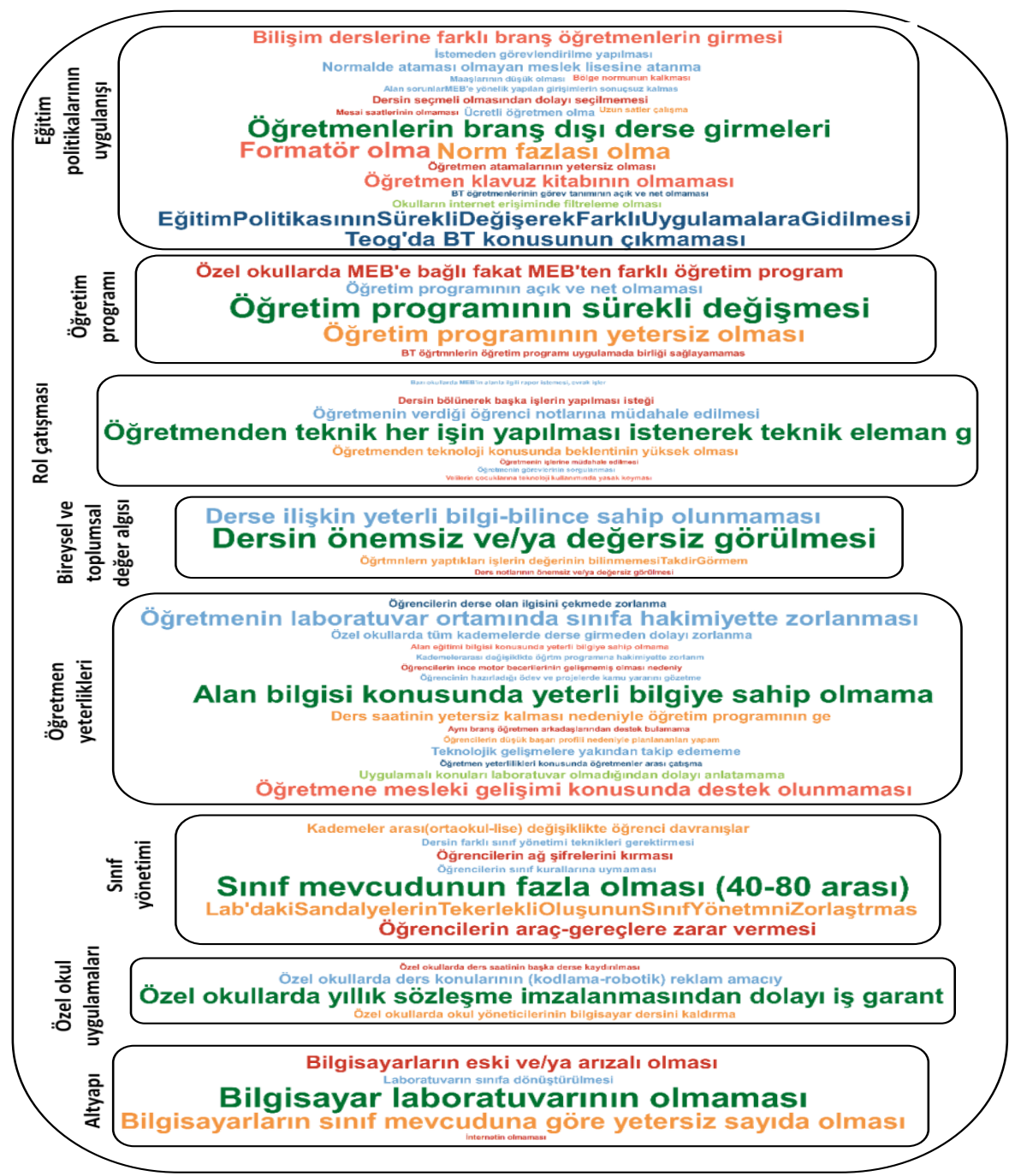

Şekil 1. Öğretmenlerin mesleki yaşamda karşılaştıkları sorunları ile ilgili kod bulutları 
Öğretmenlerin sorunlarının, eğitim politikalarının uygulanışı, öğretim programı, sınıf yönetimi, vb.. kategorilere ayrılmış olsa da bu kategorilerdeki sorunlar arasında bir ilişkinin olduğu ya da bir sorunun diğer sorunun kaynağ ya da sonucu olduğu dikkati çekmiştir. Örneğin, öğretmenlerin verdiği notlara veli ve okul yöneticileri tarafından müdahale edilmesinin ve dersin değersiz görülmesinin eğitim politikalarının uygulanışı ile ilişkili olduğu belirlenmiştir. Nitekim TEOG gibi sınavlarda öğrencilerin okul notlarının önemi olmakta ve sınavda ise BT dersine ilişkin herhangi bir soru çıkmamaktadır. Sınavda BT branşına ilişkin herhangi bir sorunun yer almaması ise beraberinde dersin önemsiz görülmesi, notların yüksek olması beklentisini ve dolayısıyla notlara müdahale sorunlarını beraberinde getirmektedir. Örneğin, öğretmenlerin teknik eleman gibi görülmesi sorunu, onların ders işlerken okul yöneticileri tarafından dersin bölünerek başka işlerin yapılması sorununa da yol açabildiği belirlenmiştir. Nitekim bu soruna ilişkin Salih öğretmen DH'sinde şunları dile getirmiştir:

“...dersin ortasında birden müdür yardımcımız içeri girdi ve "Hocam biraz aşağı odama gelebilir misin? Bilgisayarda bir sorunum var." dedi. Ben de "Hocam şu an dersteyim teneffüste geleyim." şeklinde cevap verdim. Müdür yardımcımızın cevabı "Hocam öğrenciler kendileri yapar sen aşağı gel." Yani benim orada bulunmamın bir anlamı çok da yoktu..."

Öğretmenlerin hem teknik eleman gibi görülmesi hem de derslerinin bölünmesi sorunlarının aynı zamanda değer algısı bağlamında okul yöneticilerinin dersi önemsiz-değersiz görmesi sorunuyla da ilişkili olduğu görülmektedir.

\section{Öğretmenlerin mesleki yaşamda karşılaştıkları sorunlara önerdikleri çözümler}

İkinci tema altında öğretmenlerin mesleki yaşamda karşılaştıkları sorunlara uygulayamadıkları fakat önerdikleri çözümlere yer verilmiştir (Şekil 2).

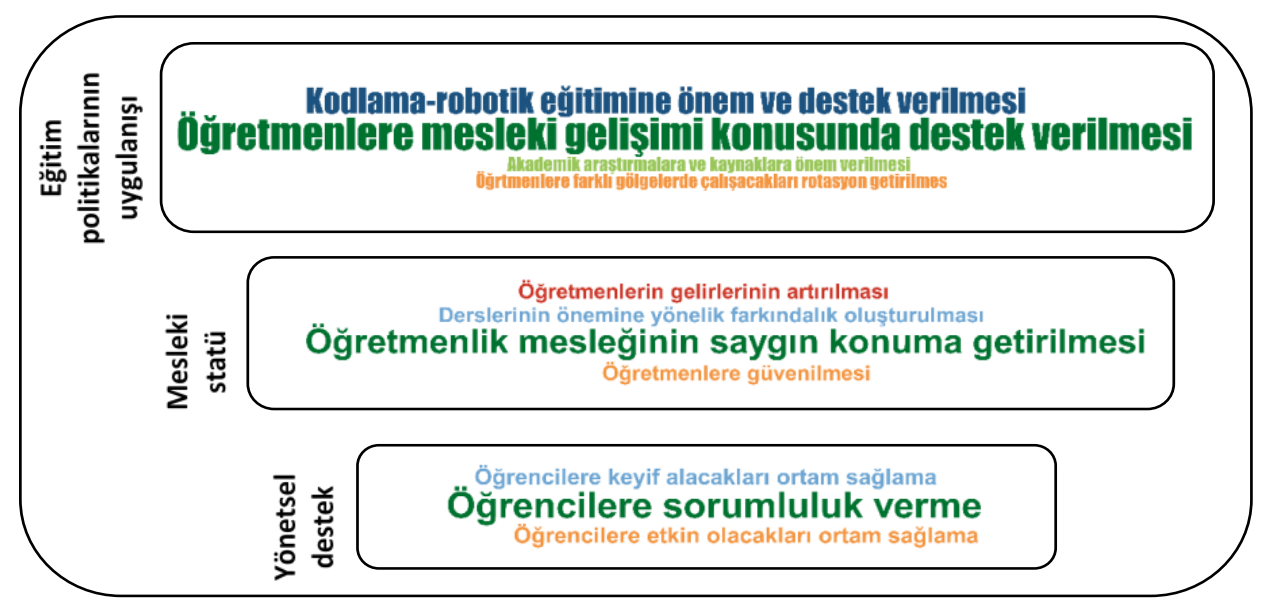

Şekil 2. Öğretmenlerin mesleki yaşamda karşılaştıkları sorunlara önerdikleri çözümlerle ilgili kod bulutları

Şekil 2'de görüldüğü gibi çözüm önerisi olarak daha çok öğretmenlere mesleki gelişimlerine yönelik verilebilecek destekler ön plana çıkmaktadır. Öğretmenlerin önerdikleri bu çözüm önerileri ile mesleki yaşamda karşılaştıkları sorunlar arasındaki ilişki incelendiğinde bu çözüm önerilerinin; öğretmen yetiştirme sürecinin ve öğretim programının yetersiz olması, öğretmenlik mesleğine yönelik saygınlığın azalması, dersin önemsiz ve/veya değersiz görülmesi, derse ilişkin yeterli bilgi-bilince sahip olunmaması, öğrenciyle ilgili en küçük bir sorunda öğretmenin suçlanması ve okullardaki disiplin yönetmeliğinin yetersizliği sorunlarından hareketle getirildiği söylenebilir. Örneğin bu konuyla ilgili Burak öğretmen hikâye çemberinde şunları söylemiştir: “...Üniversite hayatı biraz daha şey geçiyor. Hayalperest geçiyor. Word, Excel öğretmekle değil de kodlama şuan hani Milli Eğitim bir şeylerle uğraşıyor ama olmuyor yine olmuyor. Atölyeler kurulması lazım, bir şeyler yapılması lazım..."

\section{Öğretmenlerin mesleki yaşamda karşılaştıkları sorunlara uyguladıkları çözümler}

Tema 1'de yer alan öğretmenlerin mesleki yaşamda karşılaştıkları sorunlar ile tema 3'te yer alan bu sorunlara uyguladıkları çözümler arasındaki kod ilişkileri incelenerek kod-ilişki haritası oluşturulmuştur (Şekil 3).

Öğretmenlerin sorunlar karşısında daha çok öğretmen yeterlikleri (yeşil renkli kodlar) konusunda ve bu yeterlik alanında ise daha çok mesleki gelişim alt alanında çözüm uyguladıkları ortaya çıkmıştır. Bu konuda öğretmenlerin daha çok araştırıp yeni bilgiler öğrenme, kendini geliştirme ve teknolojiyle/alanla ilgili gelişmeleri takip etme adına adımlar atarak sorunlara bu şekilde çözüm buldukları belirlenmiştir. Örneğin, İlhan öğretmen bu konuyla ilgili şunları dile getirmiştir: "Aldığım öğretmen eğitimi ile mesleki hayatımı devam ettirmem özellikle bizim bölümümüz için pek yeterli değil. Kendimi geliştirmediğim sürece hep eksik kalacağımı bildiğim için sürekli olarak kendimi geliştirmeye çalışıyorum.” Başka bir örnek olarak Serkan öğretmen, hikâye çemberinde altyapı konusunda yaşadıkları sorunlara nasıl 
çözüm yolu bulduklarına ilişkin şunları dile getirmiştir: "BT öğretmeni olarak atandım. Laboratuvar yok... Bir yan binada odun ambarı $\mathrm{m} ı$ ne varmış. Orayı laboratuvar yaptık. Peki, bilgisayarlar yok nasıl yapacağız. MEB'teki kişileri tanımaya başladık. Çevremiz genişleyince bilgisayar sayımız artmaya başladı...". Altyapı eksikliklerinden hareketle MEB tarafindan hayata geçirilen FATİH (Fırsatları Arttırma ve Teknolojiyi İyileştirme Hareketi) projesinin uygulama politikasının tekrar gözden geçirilmesi gerektiği söylenebilir.

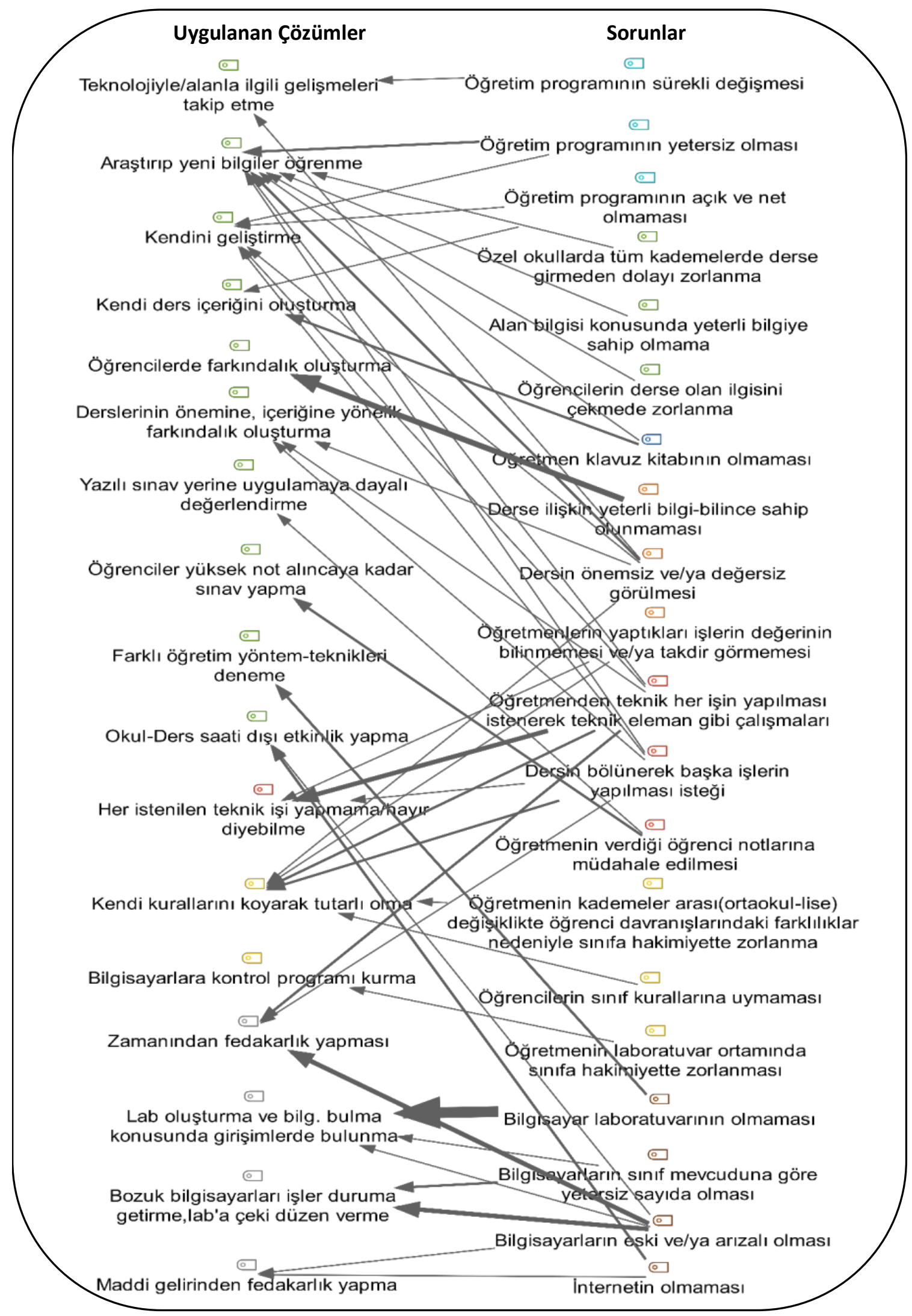

Şekil 3. Öğretmenlerin mesleki yaşamda karşılaştıkları sorunlar ve bu sorunlara yönelik uyguladıkları çözümler arasındaki ilişki 
Öğretmenlerin karşılaştıkları sorunları çözme konusunda çaba gösterdikleri, girişimlerde bulundukları, maddi ve manevi olarak fedakârlık yaptıkları dikkati çekmektedir. Ek olarak, sorunlar ve uygulanan çözümlerle ilgili olarak DHAA'larda öğretmenler arasında fikir alışverişi yapıldığı görülmüştür. Bu noktada daha az deneyimli öğretmenlerin daha deneyimli öğretmenin deneyimlerinden, önerilerinden yararlandıkları, deneyimli öğretmenlerin diğer öğretmenlere yararlı bilgiler sunduğu ortaya çıkmıştır.

\section{Mesleki yaşamın öğretmenlere katkıları}

Dördüncü tema altında mesleki yaşamın öğretmenlere dört kategoride ortaya çıkan katkılarına yer verilmiştir (Şekil 4).

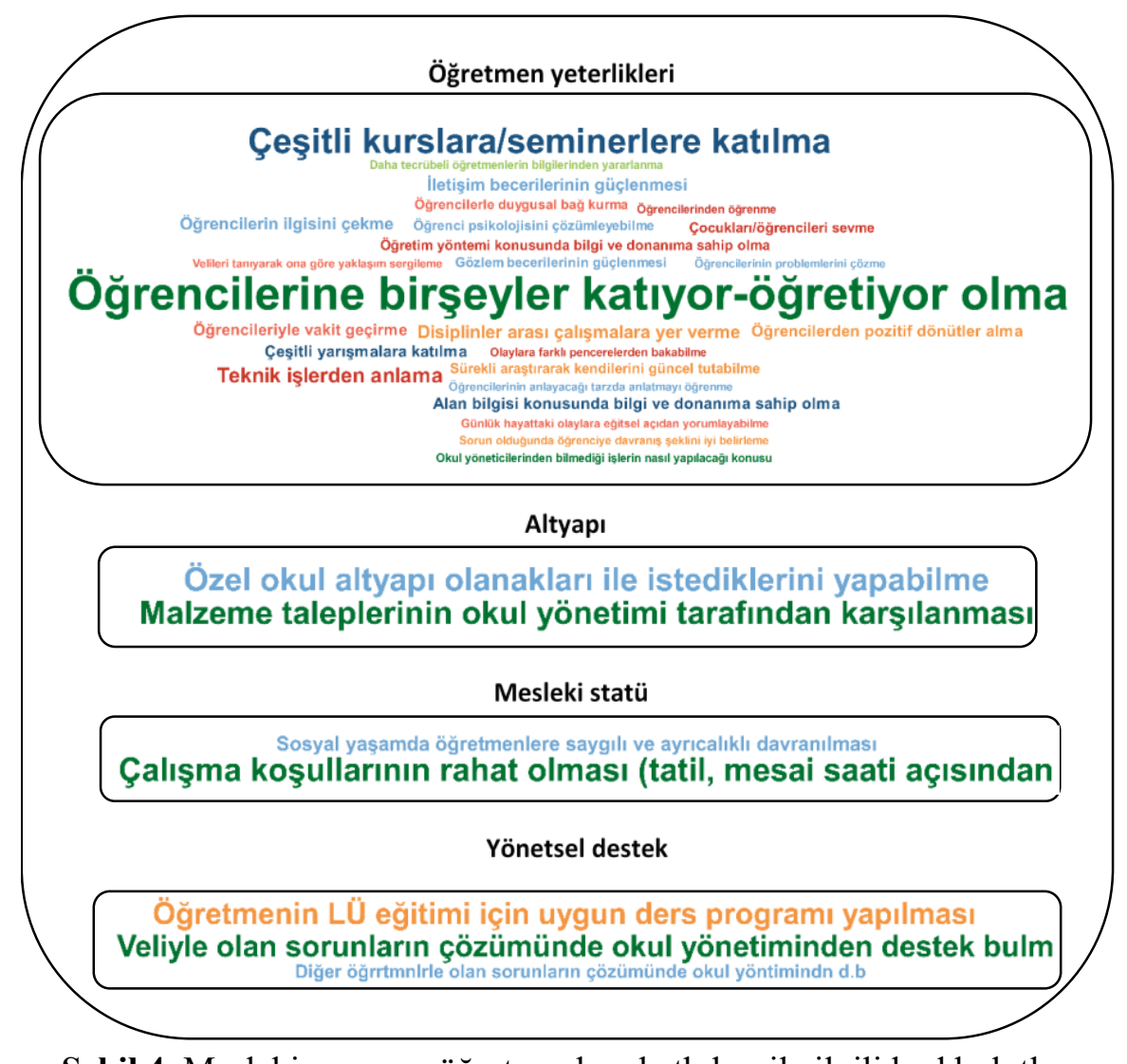

Şekil 4. Mesleki yaşamın öğretmenlere katkıları ile ilgili kod bulutları

Örneğin, kişisel ve mesleki gelişim bağlamında mesleki yaşamın öğretmenlere sağladığı en çok dile getirilen katkılardan birinin çeşitli kurslara/seminerlere katılmalarına ilişkin olduğu belirlenmiştir. Örneğin öğretmenler; işaret dili, yaratıcı drama, ilk yardım, satranç, etkileşimli tahta kullanımı, özel eğitim hizmetleri vb. birçok farklı konu ve alanda kurslara, seminerlere ve hizmet içi eğitimlere katıldıklarını dile getirmişlerdir.

Mesleki gelişim konusunda dikkat çeken bir diğer katkının ise teknik işlerden anlamalarını sağlamasına yönelik olduğu söylenebilir. Bu katkının arkasında aslında birinci tema altında yer alan bir sorun olarak görülen öğretmenlerin teknik eleman gibi çalışmaları yatmaktadır. Fakat öğretmenlerin bir kısmının bu sorunu aynı zamanda kendilerine katkı sağlayan bir durum olarak gördüğü ortaya çıkmıştır. Örneğin Haluk öğretmen bu duruma ilişkin şunları söylemiştir: “...Zaten biz bilgisayar öğretmenleri bütün işleri yapıyoruz. Zil bozulur biz gideriz falan... Aslında bunları bilmekte güzel bir şey...”

\section{Öğretmen yetiştirme sürecinin öğretmenlere katkıları}

Beşinci tema altında öğretmen yetiştirme sürecinin öğretmenlere mesleki yaşamdaki katkılarına yer verilmiştir (Şekil $5)$.

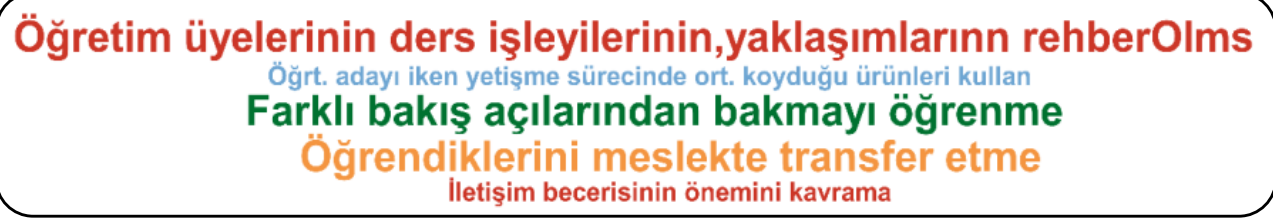

Şekil 5. Öğretmen yetiştirme sürecinin öğretmenlere katkıları ile ilgili kod bulutları 
Örnek olarak Salih öğretmenin odak grup görüşmesindeki şu sözleri verilebilir:

"Özellikle bölüm açısından ben çok memnunum, niçin diyeceksiniz? Eğitimde sözel bölümle sayısal bölümü birleştiren bakış açısını çok ilerleten, çağdaş olarak yani çağın getirdiği her şeyi görebilmenizi sağlayacak hem uzamsal olarak yani etraftaki toplumu görmek incelemek açısından geniş bir yelpaze veriyor bize, öyle mezun olduğumuzu düşünüyorum. Yani hem psikoloji biliyoruz hem sınıf yönetimi biliyoruz hem insan ilişkilerini öğrendik hem sayısal anlamda kendimizi geliştirme imkânı bulduk...”

\section{Öğretmenlerin öğretmen yetiştirme süreci ile ilgili fark ettikleri sorunlar}

Altıncı tema altında öğretmenlerin öğretmen yetiştirme sürecine ilişkin kendileri öğrenciyken fark edemedikleri fakat öğretmenliğe başladıktan sonra mesleki yaşamda fark ettikleri sorunlara yer verilmiştir (Şekil 6).

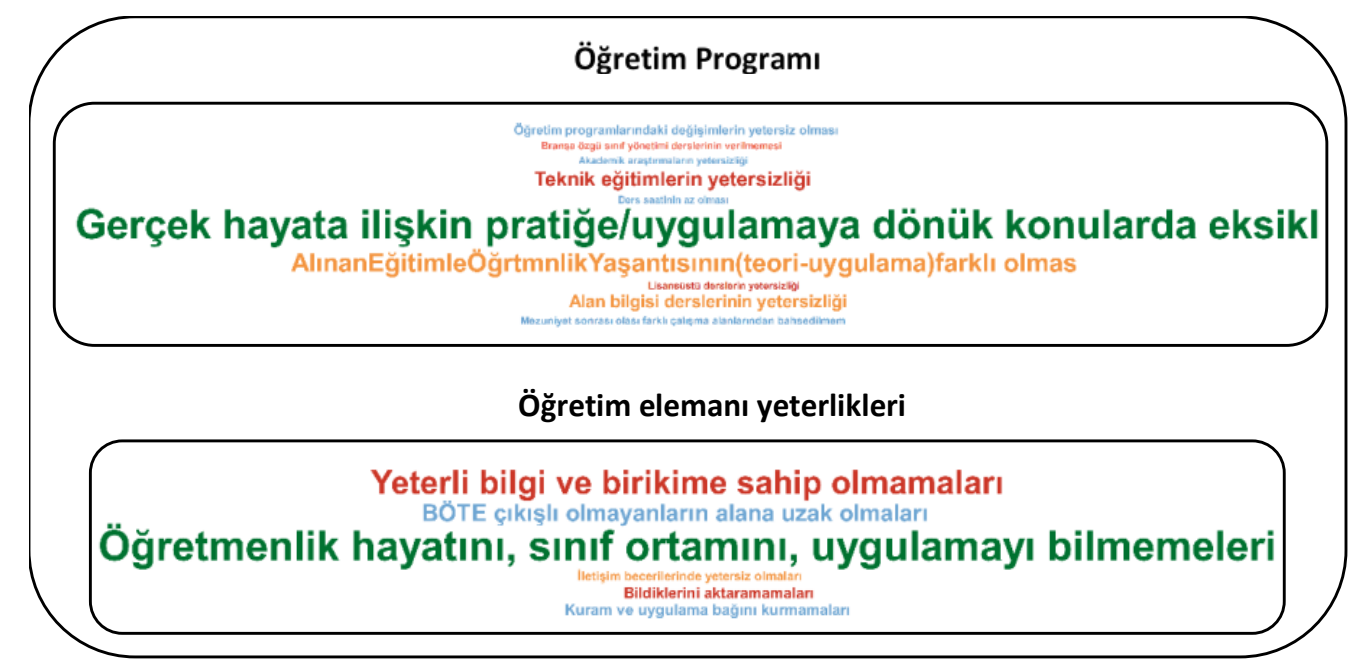

Şekil 6. Öğretmenlerin öğretmen yetiştirme süreci ile ilgili fark ettikleri sorunlar ile ilgili kod bulutları

Öğretmen yetiştirme süreci ile ilgili sorunların daha çok uygulama eksikliklerinden, kuram ve uygulama arasında bağın kurulamamasından kaynaklı olduğu ortaya çıkmıştır. Örneğin bu sorunlarla ilgili Melek ve Mahir öğretmen şunları dile getirmiştir:

Melek: “...Üniversitelerle okullar arasında en büyük uçurumda bu. Üniversiteler hep teoriye odaklandığı için, pratik sadece haftada bir iki kere staja gidip derse girip çıkmakla olmuyor. Bunu veremiyor üniversiteler...”

Mahir: “...Öğrendiklerinizle öğretmenlik bambaşka. Gerçekten öyle, bize hep ütopya eğitim sisteminden sanki yola çıkarak eğitim verdiler. Ama gerçekte farklı. Öyle şeylerle karşılaşıyoruz ki!"

\section{Öğretmenlerin öğretmen yetiştirme sürecindeki sorunlara önerdikleri çözümler}

Son olarak yedinci tema altında öğretmenlerin öğretmen yetiştirme sürecine ilişkin kendileri öğrenciyken fark edemedikleri fakat öğretmenliğe başladıktan sonra mesleki yaşamda fark ettikleri sorunlara yönelik önerdikleri çözümler irdelenmiştir. Öğretmenlerin öğretmen yetiştirme süreci ile ilgili fark ettikleri sorunlar ile bu sorunlara önerdikleri çözümler arasındaki ilişki incelenerek kod-ilişki haritası oluşturulmuştur (Şekil 7).

Öğretmenlerin öğretmen yetiştirme süreci sorunlarına yönelik olarak daha çok öğretim programlarında yapılması gerekenler konusunda çözüm önerisi getirdikleri ortaya çıkmıştır. Bu kategoride daha çok dile getirilen önerilerin ise eğitimin uygulama ağırlıklı olması, gerçek mesleki yaşantılara ilişkin video/DH izletilmesi ve programın teknolojik gelişmelere uygun şekilde güncellenmesine ilişkin olduğu ortaya çıkmıştır.

\section{Sonuç ve Tartışma}

Bu çalışmada Türkiye'nin farklı bölgelerinde yer alan şehirlerde, farklı koşullarda görev yapan 28 BT öğretmeni ile bir yıllık bir süreçte yürütülen altı farklı DHAA aracılığıyla öğretmenlerin kendi sesinden mesleki yaşamları ile ilgili deneyimleri bütüncül bir perspektifle derinlemesine irdelenerek ortaya koyulmuştur. Nitekim alanyazında DHAA'ların bireylerin deneyimlerini aktarmada ve seslerini duyurmada önemli bir araç olduğu ifade edilmektedir (Arraiz Matute et al., 2020; Şimşek, 2018; Lambert, 2013; Stewart \& Ivala, 2017; Van Galen, 2017).

Öğretmenler DHAA sürecini keyifli, eğlenceli, yararlı, rahatlatıcı, verimli, içten ve samimi bulduklarını ifade etmişlerdir. Örneğin süreç ile ilgili olarak Mahir öğretmen "Rahattık, samimiydik." ifadelerine yer vermiştir. DHAA sürecinde öğretmenler hikâye çemberi aşamasında mesleki yaşamlarında karşılaş̧ıkları durumlar konusunda birbirlerine açılma ile başlanan ve herkesin kendi DH'sini kendi sesinden anlattığı grup içi gösterim tamamlanana kadarki süreç içerisinde birbirleriyle içtenlikle iletişim kurmuşlar, fikir alış-verişinde ve birbirlerine önerilerde bulunmuşlardır. Böylece öğretmenler birbirlerine daha rahat açılarak, anlatmak istedikleri konuları açık bir şekilde dile getirip hem farklı mesleki yaşantıları görme hem de kendi süreçlerini gözden geçirme ve çıarımda bulunma şansını yakalamışlardır. Bu 
durum özellikle deneyimli ve daha az deneyimli öğretmenler arasında daha net gözlemlenmiştir. Buradan hareketle DHAA'ların içten, samimi ve güvene dayalı bir ortam sağlanarak yürütüldüğü ve öğretmenlerin mesleki gelişimlerine katk1 sağladığı söylenebilir.

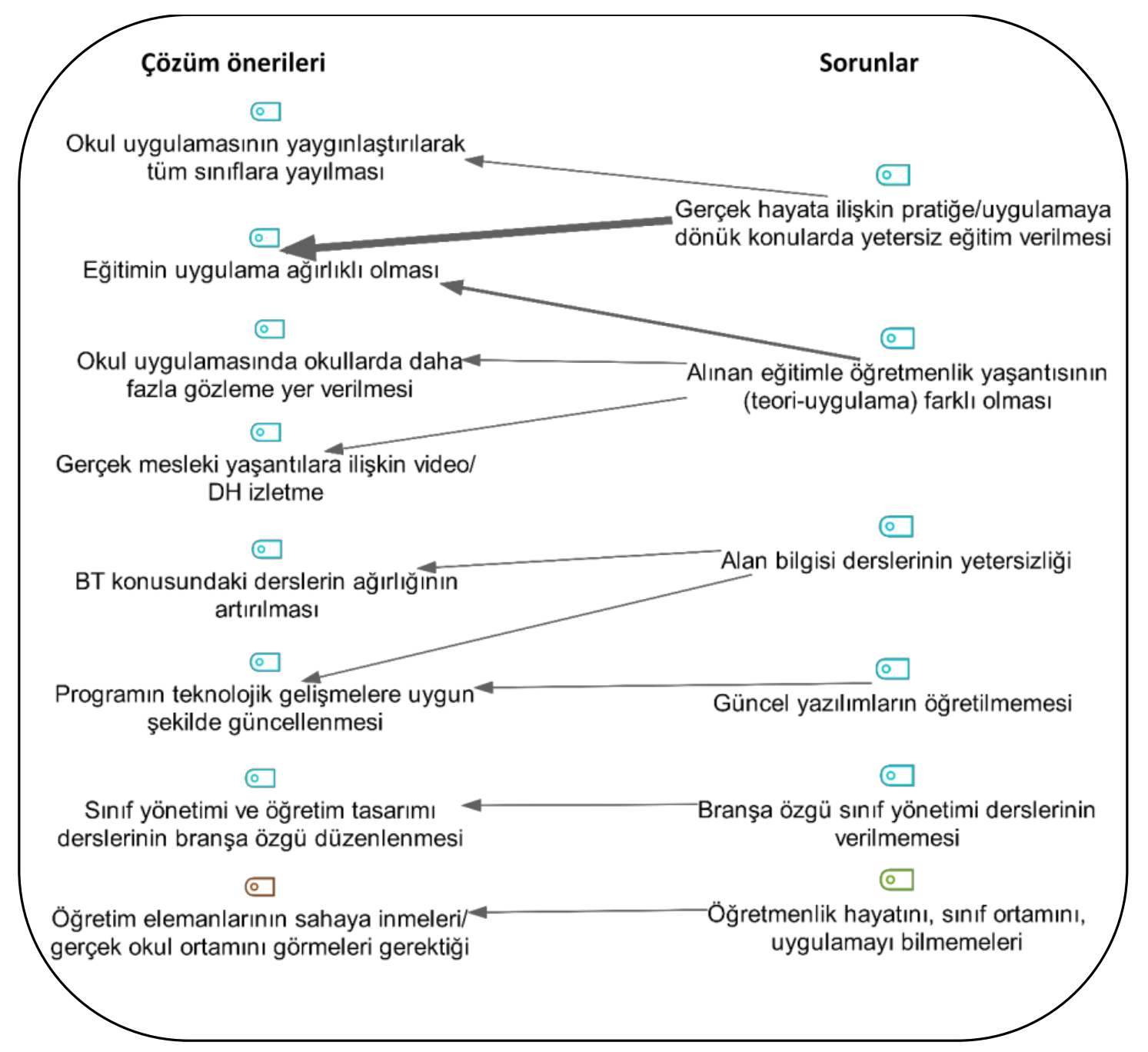

Şekil 7. Öğretmenlerin öğretmen yetiştirme süreci ile ilgili fark ettikleri sorunlar ve bu sorunlara önerdikleri çözümler arasındaki ilişki

Çalışmada veriler, bir yandan DHAA sürecindeki öğretmenlerin anlatıları ve bu süreç sonunda her bir öğretmenin oluşturmuş olduğu DH'lerle, diğer yandan da odak grup görüşmeleri ve gözlem notlarıly zaman zaman söylem ve gözlemlere bir yenisi eklenerek kimi zaman da birbirlerini destekleyici nitelikte çoklu yollardan toplanmıştır. Bu süreçte BT öğretmenlerinin daha çok sorunlarını dile getirdikleri dikkati çekmiştir. Öğretmenlerin dile getirdikleri sorunlar, eğitim politikalarının uygulanışı, rol çatışması, sınıf yönetimi, vb. kategorilere ayrılmış olsa da bu sorunların birbirleriyle iç içe geçtiği, dile getirilen bir sorunun diğer sorunun kaynağı ya da sonucu olduğu dikkati çekmiştir. Örneğin, TEOG gibi sınavlarda BT branşına ilişkin herhangi bir soru maddesinin yer almaması sorununun beraberinde dersin önemsiz ve/veya görülmesini, notların yüksek olması beklentisini ve dolayısıyla öğretmenin verdiği öğrenci notlarına veli ve yönetici müdahale sorunlarını getirdiği görülmüştür. Öğretmenlerin mesleki yaşamda karşılaştıkları sorunların, dersin hedeflerine ulaşmasında engel oluşturduğu ve öğretmenlerin stres yaşamalarına, yorulmalarına, tükenmelerine, duygu durumlarının olumsuz yönde etkilenmesine neden olduğu belirtilmektedir (Atal-Köysüren \& Deryakulu, 2017; Deryakulu, 2006; Seferoğlu, Yıldız, \& Yücel, 2014; Şişman-Eren \& Şahin-İzmirli, 2012). Bu çalışmada öğretmenler, sorunlar karşısında araştırıp yeni bilgiler öğrenerek ve kendi ders içeriklerini oluşturarak çözüm yolu bulduklarını dile getirmişlerdir. Buradan hareketle öğretmenlerin sorunlar karşısında pasif kalmadıkları, bir şeyleri değiştirmek istedikleri, değişimlerle ilgili konuş̧tukları, kimi zamanda mesleki yaşamlarında bu sorunların çözümüne yönelik eyleme geçtikleri ifade edilebilir.

Yukarıda, öğretmenlerin mesleki yaşamda karşılaştıkları sorunlar altında yer alan kategorilerin birbiriyle iç içe geçtiği örneğinin sadece bununla sınırlı olmadığı hem temaların hem de kategorilerin birbirleriyle iç içe geçtiği ortaya çıkmıştır. Örneğin öğretmen yetiştirme sürecindeki öğretim programı ile ilgili sorunların (altıncı tema) mesleki yaşamda da öğretmen yeterlikleri, öğretim programının uygulanışı, vb. kategorilerle ilgili sorunlara (birinci tema) yol açtı̆̆ 
görülmüştür. Buradan hareketle öğretmenlerin mesleki yaşama ilişkin yoğun olarak dillendirdikleri eğitim politikası, öğretim programı, öğretmen yeterlikleri, rol çatışması ve öğretmen yetiştirme süreci ile ilgili konular aşağıda sırasıyla tartışılmışıtır.

\section{Eğitim Politikaları}

Öğretmenlerin dile getirdiği eğitim politikalarının uygulanışı ile ilgili sorunların öğretmenlerin istihdamlarıyla, öğretmen atamalarıyla, BT dersiyle ilgili olduğu görülmüştür. Öğretmenler tarafından dile getirilen BT branşı özelindeki sorunlardan birinin eğitim politikasının sürekli değişerek farklı uygulamalara gidilmesi olduğu dikkati çekmektedir. Nitekim BT dersinin tarihçesi incelendiğinde 1997 yılından bu yana dersin adı, seçmeli veya zorunlu olması, dersin okutulduğu kademe, öğretim programı, değerlendirme, dersin seçim şekli ve ders kitabının yayınlanıp yayınlanmamasına yönelik zaman içinde değişikliklere gidildiği görülmektedir (BTE Derneği, 2013; TTKB, 2019). Bu değişikliklerin ise birtakım sorunları beraberinde getirdiği söylenebilir. Örneğin, dersin seçmeli olması, dersin önemsiz ve/veya değersiz görülmesi ve dersin seçilmemesi sorunlarını beraberinde getirmektedir. Alanyazından hareketle eğitim politikasının sürekli değişerek farklı uygulamalara gidilmesi sorunun sadece BT branşı özelinde olmadığı, genel bir sorun olduğu, yeni bir sorun olmadığı, yıllar önce de var olduğu ve devam eden bir sorun olduğu söylenebilir (AtalKöysüren \& Deryakulu, 2017; Tural \& Karakütük, 1991). Bu konuyla ilgili olarak ülkemizde sürekliliği olan bir eğitim politikasının yerleşemediği ve eğitim politikalarının uygulamaya aktarılmadığına ilişkin görüşlerin olduğu fakat eğitim sorunlarını çözmeye yönelik olarak kararlı bir eğitim politikasının olması gerektiği ifade edilmektedir (Tural \& Karakütük, 1991). Ek olarak öğretmen eğitimindeki kararsız ve tutarsız uygulamaların da öğretmen niteliği açısından önemli bir tehdit oluşturduğu söylenebilir (TED, 2009).

Dersin seçmeli olması sorunu ele alındığında öğretmenler, dersin seçmeli olarak görünse de bu seçim kararının öğrencilere bırakılmadığını ve okul yöneticilerin karar verdiğini dile getirmişlerdir. Nitekim alanyazında dersin seçmeli oluşu sorununun, ders seçim kararını okul yöneticilerinin verme sorununu beraberinde getirdiği fakat bu kararın öğrencilere bırakılması gerektiği ifade edilmektedir (Şişman-Eren \& Şahin-İzmirli, 2012).

Öğretmenlerin atamalarla ilgili dile getirdiği sorunlardan biri de öğretmen atamalarının yetersiz sayıda oluşuna yöneliktir. $\mathrm{Bu}$ durumdan dolayı öğretmenler okulda tek başlarına olduklarını, zümre öğretmen arkadaşlarının olmadığını, okulda onlardan beklentinin yüksek olması ve teknik eleman gibi çalışmaları nedeniyle iş yüklerinin fazla olduğunu belirtmişlerdir. Nitekim alanyazında da çoğu okulda öğretmenlerin tek başlarına olmaları nedeniyle iş yüklerinin fazla olduğu ve bunun da yorulmalarına ve tükenmelerine neden olduğu ifade edilmektedir (Deryakulu, 2006). Bu noktada çözüm önerisi olarak BT öğretmen atamalarının artırılmasının gerekliliği ortaya çıkmaktadır.

\section{Öğretim Programı}

Öğretim programı konusunda BT öğretmenleri daha çok BT dersinin öğretim programının sürekli değişmesi sorununu dile getirmişlerdir. Nitekim BT dersinin tarihçesi incelendiğinde 1997 yılından bu yana öğretim programında değişikliklere gidildiği görülmektedir (BTE Derneği, 2013; TTKB, 2019).

Öğretmenlerin dile getirdiği bir başka sorun olan BT öğretmenlerinin öğretim programını uygulamada birliği sağlayamaması sorunun ise eğitim politikalarının uygulanışı, altyapı ve öğretmen yetiştirme süreci ile ilgili sorunlarla ilişkili olduğu söylenebilir. Nitekim derse ilişkin kimi yıllarda öğretmen kılavuz kitabı bulunmamaktadır. Bazı okullarda da bilgisayar laboratuvarının ve internetin olmaması, bilgisayarların eski ve/veya yetersiz sayıda olması, vb. altyapı sorunlarının da öğretim programının uygulanışında aksaklıklara neden olduğu ve öğretmenin kendi programını mevcut koşullara göre düzenleyerek uygulamasına yol açtığı söylenebilir. Öğretmen yetiştirme süreci ile ilgili olarak da bir yandan BÖTE bölümlerinin öğretim programında yer alan derslerin içeriğinin uygulanmasında ve seçmeli ders havuzlarında çeşitlilik mevcuttur. Diğer yandan da BÖTE öğretim programlarında 1998 yılından bu yana değişime gidildiği görülmektedir (YÖK, 2018a; 2018b). Bu çeşitlilikten dolayı öğretmen adaylarının farklı yeterlik ve donanımla mezun olduğu ve bunun da öğretmenlerin mesleğe başladıklarında farklı uygulamalara gitmesine neden olduğu söylenebilir. Bu noktada öğretmen yetiştirme süreci ile ilgili olarak BÖTE öğretim programlarında birliğin sağlanmasına yönelik çalışmaların yapılmasının yararlı olacağı söylenebilir.

\section{Öğretmen Yeterlikleri}

Öğretmen yeterliklerin, öğrencilerin başarısında, kişiliklerinin biçimlenmesinde, vb. açılardan öğrencilerin eğitimi ve öğrenme- öğretme süreçlerinin kalitesi için önemli bir rolünün olduğu belirtilmektedir (European Parliament, 2008; Goe \& Stickler, 2008; Leigh \& Mead, 2005; TED, 2009). Türkiye'de ise öğretmen yeterlikleri konusundaki çalışmaların 90’lı yılların sonunda başladığı ve günümüze kadar çeşitli zamanlarda çalıştaylar düzenlenerek raporların hazırlandığ 1 görülmektedir (MEB, 2017; TED, 2009). Öğretmen yeterlikleri konusundaki son güncelleme çalışmasında her bir ögretmenlik alanı için özel alan yeterliklerini ayrı tutmak yerine genel yeterliklere yeni eklemeler (alan bilgisi ve alan eğitimi bilgisi) yapılarak bütünsel bir "Öğretmenlik Mesleği Genel Yeterlikleri”nin oluşturulduğu belirtilmektedir (MEB, 2017). Bu kapsamda yeterliklerin, "mesleki bilgi", "mesleki beceri" ve "tutum ve değerler" olmak üzere birbiriyle ilişkili ve birbirini tamamlayan üç yeterlik alanından oluştuğu, bu yeterlik alanlarının altında ise toplamda 11 
yeterlik ve bunlara ilişkin 65 göstergenin yer aldığı görülmektedir (MEB, 2017). BT öğretmenlerinin anlatımları bu yeterlik alanları ve yeterlikler açısından incelendiğinde öğretmenlerin BT branşı özelinde alan bilgisi ve alan eğitimi bilgisi, öğretme ve öğrenme sürecini yönetme, kişisel ve mesleki gelişim, iletişim ve işbirliği konularında mesleki yaşamda sorunlar yaşadıkları; öğrenme ortamları oluşturma konusunda sorunlara yönelik çözüm önerilerinin olduğu; mesleki beceri ve tutum ve değerler yeterlik alanlarının tüm yeterliklerine ilişkin sorunlara yönelik uyguladıkları çözümlerin olduğu; kişisel ve mesleki gelişim, iletişim ve işbirliği, öğrenciye yaklaşım, alan bilgisi ve alan eğitimi bilgisi konularında ise mesleki yaşamın kendilerine katkılarının olduğu belirlenmiştir. Mesleki bilgi konusunda öğretmenlerin en çok dile getirdiği sorunun alan bilgisi konusunda kendilerini yetersiz görmelerine ilişkin olduğudur. Bu sorunun öğretmenlerin aldıkları öğretmen eğitiminin yetersizliğinden, kuram ve uygulama arasındaki farklılıklardan kaynaklandığı söylenebilir.

Öğretme ve öğrenme sürecini yönetme yeterliğine ilişkin öğretmenlerin sorunları incelendiğinde bu sorunların çoğunluğunun dersin işlendiği fiziksel koşullardan kaynaklandığı görülmektedir. Örneğin laboratuvar ortamında ders işlenmesinden dolayı öğretmenin sınıfa hâkimiyette zorlanması, kendini yetersiz görmesi, öğrencileri derse ilgisini çekmede zorlanması, ders saatinin yetersiz kalması ve süreyi ayarlayamamadan kaynaklı öğretim programının gerisinde kalması gibi sorunların öne çıktığı dikkati çekmektedir.

Derse ayrılan sürede planlanan uygulamaların yapılamaması sorununun, ders süresinin yetersiz olması, sinıfin kalabalık oluşu, laboratuvar ortamında sınıfa hâkimiyette zorlanılması ve bilgisayarların sınıf mevcuduna göre yeterli sayıda olmaması, bilgisayarların eski ve/veya arızalı olması, vb. altyapı eksikliği sorunlarıyla ilgili olduğu belirlenmiştir. Alanyazında bu sorunlara yönelik olarak ders saatinin artırılması gerektiğine ilişkin öneri getirildiği görülmektedir (Deryakulu, 2006; Erçetin \& Durak, 2017; Şişman-Eren \& Şahin-İzmirli, 2012).

Öğretmenler tarafından dile getirilen sorunlardan biri uygulamalı konuların laboratuvar olmadığından dolayı anlatılamaması ve kendilerinin bu durum karşısında öğretme-öğrenme sürecini yönetme konusunda sıkıntı yaşamasına ilişkindir. Bu sorun, öğretmenlerin aldığı öğretmen eğitiminin yetersiz kaldığını ve kuram ve uygulamada farklıların olduğunu göstermektedir. Bu sorun karşısında öğretmenlerin öğretim programını yazıldığı gibi uygulayamadığı, gerisinde kaldığ 1 ve kendilerinin ders içeriği oluşturarak ve farklı öğretim yöntem ve teknikleri deneyerek soruna çözüm yolu bulmaya çalıştıkları dikkati çekmektedir.

Öğretmenler tarafindan dile getirilen bir başka sorun ise özel okullarda görev yapan öğretmenlerin tüm kademelerde derse girmeden dolayı zorlanmalarına ve öğretme ve öğrenme sürecini yönetmede kendilerini yetersiz görmelerine ilişkindir. Nitekim öğretmenler, ilkokul ve ortaokul kademelerine atanmalarına yönelik mezun olmakta ve buna göre eğitim almaktadırlar. Fakat özel okulları tercih eden ve/veya atanamadıkları için özel okullarda çalışmak zorunda kalan öğretmenlerin anaokulu, ilkokul, ortaokul ve lise olmak üzere tüm kademelerde derse girdikleri görülmektedir. Bu noktada öğretmenler, aldıkları eğitimin yetersiz olduğunu, kendilerini yetersiz gördüklerini ve bundan dolayı da öğretme ve öğrenme sürecini yönetmede zorlandıklarını dile getirmişlerdir. Fakat bu sorun karşısında sürekli araştırarak yeni bir şeyler öğrenmeye çalıştıklarını ve kendilerini geliştirdiklerini de belirtmektedirler.

\section{Rol Çatışması}

BT öğretmenlerinin en çok dile getirdiği sorunlardan birinin rol çatışması ile ilgili olduğu dikkati çekmektedir. Rol çatışmasının, velilerin, okul yöneticilerinin, öğrencilerin öğretmene ilişkin farklı görüşlere sahip olması nedeniyle öğretmenin rolüne ilişkin algılardaki farklılıklardan ve öğretmene ilişkin beklentilerden kaynaklanan çelişkilerden kaynaklandığı belirtilmektedir (Ceylan \& Ulutürk, 2006; Fisher, 2001). Nitekim öğretmenler, okul yöneticilerinin, diğer öğretmenlerin ve velilerin kendilerinden görev tanımlarında yer almayan pek çok görev ve sorumluluğun yerine getirilmesini beklediklerini dile getirmişlerdir.

Rol çatışması ile ilgili dikkat çeken bir sorunun öğretmenin verdiği öğrenci notlarına müdahale yapılması konusunda olduğu söylenebilir. Öğretmenler, bu müdahalenin hem okul yöneticileri hem de veliler tarafından yapıldığını dile getirmişlerdir. Öğretmenler bu müdahalenin kimi zaman baskı kimi zaman da kendilerinden habersiz sistemlerine girerek notların doğrudan değiştirilmesi olarak karşılarına çıktığını dile getirmişlerdir. Bu noktada etik ve ahlak dışı davranışların sergilendiği dikkati çekmektedir.

BT öğretmenlerinin rol çatışması ile ilgili yaşadığı sorunların arkasında yatan nedenlerin okul yöneticilerinin ve velilerin derse ilişkin algılarından kaynaklandığ yani dersin ve ders notlarının önemsiz ve/veya değersiz görülmesi, derse ilişkin yeterli bilgi-bilince sahip olunmaması ile ilgili olduğu söylenebilir. Diğer bir yandan, öğretmenlerin görev ve sorumlulukları dışındaki işleri de yerine getirmelerine rağmen bu yaptıkları karşılığında herhangi bir takdir görmediklerini dile getirmeleri ayrı bir sorunu işaret etmektedir. Rol çatışmasının ise öğretmenler için stres kaynağı olduğu ve mesleki tükenmişliklerine sebep olduğu belirtilmektedir (Fisher, 2001; Deryakulu, 2006).

Öğretmenlerin bu tür sorunlar karşısında ise kimi zaman her istenileni yapmayarak, zamanla hayır demeyi öğrenerek, kendi kurallarını koyup tutarlı olarak ve derslerinin içeriğine/önemine yönelik farkındalık oluşturmaya çalışarak çözüm yolu bulmaya çalıştıkları görülmektedir. Alanyazında bu sorunlara yönelik dersin statüsünün seçmeli yerine zorunlu olması, ders saatinin arttırılması ve öğretim programının güncellenmesi konusunda çözüm önerilerinin getirildiği görülmektedir (Şerefoğlu-Henkoğlu \& Yıldırım, 2012; Şişman-Eren \& Şahin-İzmirli, 2012). 


\section{Öğretmen Yetiştirme Süreci}

DHAA'larda öğretmenlerin kendileri öğrenciyken fark edemedikleri fakat öğretmenliğe başladıktan sonra öğretmen yetiştirme süreci ile ilgili fark ettikleri sorunların olduğu ve bunların daha çok gerçek hayata ilişkin pratiğe/uygulamaya dönük konularda yetersiz eğitim verilmesine ve alınan eğitimle öğretmenlik yaşantısının (kuram-uygulama) farklı olmasına ilişkin olduğu ortaya çıkmıştır. Bu noktada, verilen kuramsal eğitimin zayıflı̆̆ının uygulamada yetersiz kalınması; uygulamadaki eksikliğin de kuramı besleyememe sorununu beraberinde getirdiği söylenebilir. Kuram ve uygulamanın birbirini etkilediği ve döngüsel bir birbirini besleme durumunun olduğunun göz önünde bulundurulmas1 gerektiği ifade edilebilir. Nitekim kuram ve uygulama bağının, öğretmen eğitiminin temel unsurlarından biri olduğu dile getirilmektedir (NIE, 2009). Alanyazın incelendiğinde ise öğretmen eğitiminde sıkça dile getirilen sorunlardan birisinin kuram ile uygulama arasında boşluk olması, bağın kurulamaması veya dengenin sağlanamamasına ilişkin olduğu ve bu noktada çeşitli önerilerin getirildiği görülmektedir (Álvarez Álvarez, 2015; Ching, 2014; NIE, 2009; Özçınar \& Deryakulu, 2011; YÖK, 2007; Zeichner, 2010). Bu çalışmada da öğretmenler, öğretmen eğitiminde gerçek mesleki yaşantılara ilişkin video izletilmesi konusunda çözüm önerisi getirmişlerdir. Buradan hareketle bu çalışmada ortaya çıkan DH'lerin öğretmen eğitiminde kullanılabileceği söylenebilir. DH'lerin öğretmen eğitiminde kullanılması durumunda öğretmen adaylarının öğretmenlik mesleğine ilişkin deneyimlere dayalı somut örnekler görebileceği ve öğretmenlerin okul ortamı, öğretim programı, velilerle iletişim vb. konularla ilgili pratik bilgilerini elde edebilecekleri, böylelikle kuram ve uygulama bağının kurulabilmesi için somut adımlar atılabileceği ve bu konunun yeni çalışmalara kapı açtı̆̆ ileri sürülebilir.

DHAA'larda öğretmenlerin öğretmen yetiştirme sürecindeki sorunlara ilişkin dile getirdikleri çözüm önerilerinin bir kısmının ise

- öğretim programının teknolojik gelişmelere uygun şekilde güncellenmesine

- farklı okul ve kademelerde okul uygulaması yapılmasina

- okul uygulamasının yaygınlaştırılarak tüm sınıflara yayılmasına

- okul uygulamasında okullarda daha fazla gözleme yer verilmesine

ilişkin olduğu ortaya çıkmıştır. Öğretmenlerin bu önerilerinin 2018 'de değişen yeni BÖTE lisans programı ile kısmen karşılık bulabileceği söylenebilir.

Sonuç olarak, bu çalışma ile Türkiye' de eğitsel bağlamda BT branşı özelinde farklı koşullarda çalışan, farklı yeterlik ve donanıma sahip olan öğretmenlerin deneyimlerinin kendi sözleri ve sesleri ile DHAA’larda işbirlikli bir süreç sonunda ürettikleri DH'leri yoluyla dolaşıma girmiştir. Bu dolaşıma giren DH'lerin ilgili taraflarca aynı içtenlikle izlenilmesine ihtiyaç olduğu ve bu DH'lerin izlenilmesi durumunda da okul yöneticileri, öğretmenler, veliler, öğretmen adayları, öğretim elemanları, eğitim politikalarının yürütülmesinden sorumlu MEB, öğretmen yetiştirme sürecinden sorumlu YÖK gibi ilgili tarafların işbirliğini sağlamaya ve somut adımlar atılmasına yönelik firsatların oluşacağı söylenebilir. Nitekim bir grup performansı olarak DHAA'larda katılımcıların işbirliği yoluyla sosyal kimliklerini oluşturdukları, DH'lerin katılımcıların önemli konuları ele almalarına fırsat sunduğu ve bunların da daha fazla sayıdaki kişiyi harekete geçirebilecek bir grup kültürü oluşturabileceği ifade edilmektedir (Gubrium \& Turner, 2011). Ek olarak dolaşımda olan DH'lere, izlenen hedef kitle tarafından nasıl anlamlar yüklendiğini incelemeye yönelik yeni çalışmaların yürütülmesine gereksinim olduğu söylenebilir. 


\section{Kaynakça / References}

Álvarez Álvarez, C. (2015). Can teachers bridge the theory-practice gap? An ethnographic study of a teacher. US-China Education Review B, 5(4), 233-244.

Ang, I. (1989). Beyond self-reflexivity. Journal of Communication Inquiry, 13(2), 27-29.

Arraiz Matute, A., Da Silva, L., Pendleton Jiménez, K., \& Smith, A. (2020). The sex of it all outness and queer women's digital storytelling in teacher education. Teaching Education, 31(1), 98-111.

Atal-Köysüren, D., \& Deryakulu, D. (2017). Eğitim politikalarındaki değişimlerin bilişim teknolojileri öğretmenlerinin duyguları üzerindeki etkisi. Ĕgitim ve Bilim, 42(190), 67-87.

Bahçeci, F., \& Genç, Z. (2013). Bilişim teknolojileri öğretmenlerinin üniversitede aldıkları eğitim-öğretimin mesleki hayata etkilerine yönelik görüşleri. Gaziantep Üniversitesi Sosyal Bilimler Dergisi, 12(2), 315-324.

BTE Derneği. (2013). Türkiye’de ilk ve ortaokullarda (ilköğretim) okutulan bilişim teknolojileri derslerinin tarihi. Erişim: http://bte.org.tr/bte-dernegi/btderslerinin-tarihcesi/

Ceylan, A., \& Ulutürk, Y. H. (2006). Rol belirsizliği, rol çatışması, iş tatmini ve performans arasındaki ilişkiler. Doğuş Üniversitesi Dergisi, 7(1), 48-58.

Ching, C. P. (2014). Linking theory to practice: A case-based approach in teacher education. Procedia-Social and Behavioral Sciences, 123, 280-288.

de Jager, A., Fogarty, A., Tewson, A., Lenette, C., \& Boydell, K. M. (2017). Digital storytelling in research: A systematic review. The Qualitative Report, 22(10), 2548-2582.

Deryakulu, D., \& Akbaba-Altun, S. (2014). Classroom management in middle school computer labs: The Turkish experience. Journal for Computing Teachers, 1(1), 1-11.

Deryakulu, D. (2006). Burnout in Turkish computer teachers: Problems and predictors. International Journal of Educational Reform, 15(3), 370-385.

Erçetin, S. S., \& Durak, A. (2017). Ortaokullarda bilişim teknolojileri ve yazılım dersinin işlenişi, yaşanan problemler ve çözüm önerileri: Öğretmen görüşleri. Bartın Üniversitesi Eğitim Fakültesi Dergisi, 6(1), 159-176.

Erdoğan, M., Kurşun, E., Tan-Şişman, G., Saltan, F., Gök, A., \& Yıldız, İ. (2010). Sınıf yönetimi ve sınıf içi disiplin problemleri, nedenleri ve çözüm önerileri üzerine nitel bir araştırma: Bilişim teknolojileri dersi örneği. Kuramdan Uygulamaya Eğitim Bilimleri, 10(2), 853-891.

Eren, E., \& Uluuysal, B. (2012). Bilişim teknolojileri (BT) öğretmenlerinin mesleki sorunları ve çözüm önerileri: Okul müdürü ve BT öğretmenlerinin görüşleri. Mersin Üniversitesi Eğitim Fakültesi Dergisi, 8(3), 152-171.

European Parliament. (2008). European Parliament resolution of 23 September 2008 on improving quality of teacher education (2008/2068(INI)). Access: http://www.europarl.europa.eu/sides/getDoc.do?pubRef=-//EP//TEXT+TA+P6-TA-2008$0422+0+\mathrm{DOC}+\mathrm{XML}+\mathrm{V} 0 / / \mathrm{EN}$

Fisher, R. T. (2001). Role stress, the type A behavior pattern, and external auditor job satisfaction and performance. Behavioral Research in Accounting, 13(1), 143-170.

Gachago, D., Ivala, E., Chigona, A., \& Condy, J. (2015). Owning your emotions or sentimental navel-gazing: Digital storytelling with South African pre-service student educators. Cultural Science Journal, 8(2), 22-42.

Goe, L., \& Stickler L. M. (2008). Teacher quality and student achivement: Making the most of recent research. Washington, D.C.: National Comprehensive Center for Teacher Quality.

Gubrium, A., \& Turner, K. N. (2011). Digital storytelling as an emergent method for social research and practice. In S. N. HesseBiber (Ed.), Handbook of Emergent Technologies in Social Research (pp. 469-491) New York, NY: Oxford University Press.

Hartley, J., \& McWilliam, K. (2009). Computational power meets human contact. In J. Hartley \& K. McWilliam (Eds.), Story circle: Digital storytelling around the world (pp. 3-15). Singapore: Wiley-Blackwell Publishing. 
Hausknecht, S., Vanchu-Orosco, M., \& Kaufman, D. (2016). New ways to tell my story - evaluation of a digital storytelling workshop for older adults. Proceedings of the 8th International Conference on Computer Supported Education, 2, (pp. 231239).

Krippendorff, K. (2004). Content analysis: An introduction to its methodology (2nd ed.). Thousand Oaks, CA: Sage.

Lambert, J. (2013). Digital storytelling: Capturing lives, creating community (4th ed.). New York, NY: Routledge.

Leigh, A., \& Mead, S. (2005). Lifting teacher performance (Policy Report - Progressive Policy Institute). Access: https://files.eric.ed.gov/fulltext/ED491196.pdf

MEB. (2017). Ö̆̆retmenlik mesleği genel yeterlikleri. Erişim: http://oygm.meb.gov.tr/www/ogretmenlik-meslegi-genelyeterlikleri/icerik/39

Miles, M. B., \& Huberman, A. M. (1994). Qualitative data analysis (2nd ed.). Thousand Oaks, CA: Sage.

Neuendorf, K. A. (2002). The content analysis guidebook. Thousand Oaks, CA: Sage.

NIE. (2009). A teacher education model for the 21st century. Access: https://www.nie.edu.sg/docs/default-source/te21_docs/te21online-version---updated.pdf?sfvrsn=2

Nuñez-Janes, M. (2016). When ethnography relates: Reflections on the possibilities of digital storytelling. Anthropology \& Education Quarterly, 47(3), 235-239.

Oğuz, H. Ş. (2015). The potential of digital storytelling as an ethnographic research technique in social sciences. Cultural Science Journal, 8(2), 244-260.

Seferoğlu, S. S., Yıldız, H., \& Yücel, Ü. A. (2014). Öğretmenlerde tükenmişlik: Tükenmişliğin göstergeleri ve bu göstergelerin çeşitli değişkenler açısından incelenmesi. Ĕgitim ve Bilim, 39(174), 348-364.

Stacey, G., \& Hardy, P. (2011). Challenging the shock of reality through digital storytelling. Nurse Education in Practice, 11(2), 159-164.

Stenhouse, R., Tait, J., Hardy, P., \& Sumner, T. (2013). Dangling conversations: Reflections on the process of creating digital stories during a workshop with people with early-stage dementia. Journal of Psychiatric and Mental Health Nursing, $20(2), 134-141$.

Stewart, K. D., \& Ivala, E. (2017). Silence, voice, and "other languages": Digital storytelling as a site for resistance and restoration in a South African higher education classroom. British Journal of Educational Technology, 48(5), 1164-1175.

Şerefoğlu-Henkoğlu, H., \& Yıldırım, S. (2012). Türkiye'deki ilköğretim okullarında bilgisayar eğitimi: Kuram ve uygulamadaki farklılıklar. Ankara Üniversitesi Eğitim Bilimleri Fakültesi Dergisi, 45(1), 23-61.

Şimşek, B. (2018). İletişim çalışmaları bağlamında dijital hikâye anlatımı: Kavramlar ve Türkiye deneyimi. İstanbul: Alternatif Bilişim.

Şimşek, B. (2013). Hikâye anlattıran, hikâyemi anlatan, kendi hikâyesini yaratan çember: Dijital hikâye anlatımı atölyesinde birbirine karışan sesler/im. Hakan Ergül (Ed.), Sahanın sesleri: İletişim araştırmalarında etnografik yöntem içinde (ss. 279308). İstanbul: İstanbul Bilgi Üniversitesi Yayınları.

Şimsek, B., \& Erdener, B. (2012). Digital visual skills education for digital inclusion of elder women in the community. ProcediaSocial and Behavioral Sciences, 46, 4107-4113.

Şimşek, B., Usluel, Y. K., Sarıca, H. Ç., \& Tekeli, P. (2018). Türkiye'de eğitsel bağlamda dijital hikâye anlatımı konusuna eleştirel bir yaklaşım. Eğitim Teknolojisi Kuram ve Uygulama, 8(1), 158-186.

Şişman-Eren, E., \& Şahin-İzmirli, Ö. (2012). İlköğretim okul müdürü ve bilişim teknolojileri öğretmenlerine göre bilişim teknolojileri dersinde yaşanan sorunlar ve çözüm önerileri (Eskişehir ili örneği). Kuram ve Uygulamada Eğitim Bilimleri, 12(4), 2861-2888.

TTKB. (2019). Geçmişten günümüze kurul kararlarl ve fihristleri. Erişim: http://ttkb.meb.gov.tr/www/gecmisten-gunumuze-kurulkararlari-ve-fihristleri/icerik/152

TED. (2009). Öğretmen yeterlikleri. Ankara: Adım Okan Matbaacılık. 
Topu, F. B., \& Göktaş, Y. (2012). Bilişim teknolojileri öğretmenlerinin üstlendikleri roller ve onlardan beklentiler. Kuram ve Uygulamada Eğitim Bilimleri, 12(1), 461-478.

Tural, N., \& Karakütük, K. (1991). Eğitim politikası. Eğitim ve Bilim, 15(82), 16-24.

Van Galen, J. A. (2017). Agency, shame, and identity: Digital stories of teaching. Teaching and Teacher Education, 61, 84-93.

Wu, J., \& Chen, D. T. V. (2020). A systematic review of educational digital storytelling. Computers \& Education, $147,103786$. doi:10.1016/j.compedu.2019.103786

Yeşiltepe, G. M., \& Erdoğan, M. (2013). İlköğretim bilişim teknolojileri öğretmenlerinin mesleğe yönelik sorunları, bu sorunların nedenleri ve çözüm önerileri. Gazi Üniversitesi Eğitim Fakültesi Dergisi, 33(3), 495-530.

YÖK. (2018a). Öğretmen Yetiştirme Lisans Programları. Erişim: https://www.yok.gov.tr/kurumsal/idari-birimler/egitim-ogretimdairesi/yeni-ogretmen-yetistirme-lisans-programlari

YÖK. (2018b). Bilgisayar ve Öğretim Teknolojileri Öğretmenliği Lisans Programı. Erişim: https://www.yok.gov.tr/kurumsal/idaribirimler/egitim-ogretim-dairesi/yeni-ogretmen-yetistirme-lisans-programlari

Yuksel-Arslan, P., Yildirim, S., \& Robin, B. R. (2016). A phenomenological study: Teachers' experiences of using digital storytelling in early childhood education. Educational Studies, 42(5), 427-445.

Zeichner, K. (2010). Rethinking the connections between campus courses and field experiences in college-and university-based teacher education. Journal of Teacher Education, 61(1-2), 89-99. 